



\section{Teelt van sorghum als voedergewas lijkt perspectiefvol in Nederland}

G.J. Kasper

Wageningen Livestock Research 
Kasper, G.J ., Teelt van sorghum als voedergewas lijkt perspectiefvol in Nederland.

Wageningen Livestock Research, Rapport 1064.

\section{Samenvatting NL}

Sorghum kan in korte tijd veel voedingsstoffen opnemen, ook op armere en droge gronden, en gaat efficiënt om met voedingsstoffen, vooral stikstof en water. Het gewas groeit goed op gronden waar ook snijmaïs het goed doet. Recente proefveldonderzoeken in Nederland tonen ten opzichte van maïs gelijke tot $25 \%$ hogere opbrengsten (ds/ha/jaar), hogere gehalten aan ruw-eiwit (tot $69 \%$ ) en zetmeel (-10 tot $+24 \%$ ). Kennishiaten zijn: 1 ) kennis over de voederwaarde, 2) gebrek aan praktische kengetallen over teelt, fermentatie en dierprestaties, 3) combiteelt winterrogge-sorghum in het groeiseizoen en 4) tussenteelt van sorghum bij continuteelt van snijmaïs.

\section{Summary UK}

Sorghum absorbs a lot of nutrients in a short period of time, even on rather poor and dry soils. The crop has a favourable nitrogen and water use efficiency. The crop grows well on soils where maize grows well too. Recent field trial studies in the Netherlands show equal or higher than $25 \%$ yields (dry matter/ha/year), higher levels of crude protein (up to $69 \%$ ) and starch (-10\% to $+24 \%$ ) than maize. Knowledge gaps are: 1) feed evaluation characteristics, 2) practical data on cultivation, fermentation and animal performance, 3) combi-cultivation winter rye and sorghum per growing season, and 4) intercropping of sorghum in continuous maize cropping.

Dit rapport is gratis te downloaden op https://doi.org/10.18174/427964 of op www.wur.nl/livestock-research (onder Wageningen Livestock Research publicaties).

\section{(C) 2017 Wageningen Livestock Research}

Postbus 338, 6700 AH Wageningen, T 03174839 53, E info.livestockresearch@wur.nl, www.wur. nl/livestock-research. Wageningen Livestock Research is onderdeel van Wageningen University \& Research.

Wageningen Livestock Research aanvaardt geen aansprakelijkheid voor eventuele schade voortvloeiend uit het gebruik van de resultaten van dit onderzoek of de toepassing van de adviezen.

Alle rechten voorbehouden. Niets uit deze uitgave mag worden vermenigvuldigd en/of openbaar gemaakt worden door middel van druk, fotokopie, microfilm of op welke wijze dan ook zonder voorafgaande toestemming van de uitgever of auteur.

De certificering volgens ISO 9001 door DNV onderstreept ons kwaliteitsniveau. Op als onze onderzoeksopdrachten zijn de Algemene Voorwaarden van de Animal Sciences Group van toepassing. Deze zijn gedeponeerd bij de Arrondissementsrechtbank Zwolle. 


\section{Inhoud}

$\begin{array}{ll}\text { Woord vooraf } & 5\end{array}$

$\begin{array}{ll}\text { Samenvatting } & 7\end{array}$

$\begin{array}{ll}\text { Summary } & 9\end{array}$

1

I nleiding

11

$\begin{array}{lll}1.1 & \text { Doel } & 11\end{array}$

1.2 Leeswijzer 11

2

$\begin{array}{ll}\text { Sorghumteelt } & 12\end{array}$

$\begin{array}{lll}2.1 & \text { Verschijningsvorm } & 12\end{array}$

2.2 Milieuomstandigheden 12

$\begin{array}{lll}2.3 & \text { Ziekten en plagen } & 13\end{array}$

$\begin{array}{lll}2.4 & \text { Productie en voederwaarde } & 14\end{array}$

3

$\begin{array}{ll}\text { Toepassing als diervoeder } & 15\end{array}$

$\begin{array}{lll}3.1 & \text { Alternatief van maïs } & 15\end{array}$

3.1.1 Buiten de EU 15

$\begin{array}{ll}3.1 .2 \text { Europa } & 15\end{array}$

$\begin{array}{ll}3.1 .3 \text { Nederland } & 17\end{array}$

$\begin{array}{ll}3.1 .4 \mathrm{C} \text {-vastlegging in bodem } & 20\end{array}$

$4 \quad$ Introductie sorghum in Nederland? $\quad 22$

$5 \quad$ Conclusies en aanbevelingen $\quad 24$

5.1 Conclusies $\quad 24$

5.2 Aanbevelingen $\quad 25$

$\begin{array}{lr}\text { Literatuur } & 26\end{array}$

$\begin{array}{lll}\text { Bijlage } 1 & \text { Drogestofpercentages sorghum } & 29\end{array}$ 



\section{Woord vooraf}

Sorghum is het belangrijkste graangewas in Afrika. Op dit moment is het gewas van belang in de VS als vervanger van maïs bestemd voor veevoer. Het graangewas sorghum is tot nu toe redelijk onbekend in Europa. In Nederland wordt graansorghum op kleine schaal geproduceerd. Het graan is glutenvrij. Dit is nuttig voor het toenemend aantal mensen met glutenallergie. Naast glutenvrije bakkersproducten kunnen ook sappen en bieren worden gemaakt.

Van bepaalde soorten sorghum kan de stengel dienen als grondstof voor bouwmaterialen, de cellulose, suikers en zetmeel kunnen gebruikt worden voor de productie van plastics of biobrandstof. Sorghum is zouttolerant, waardoor het als gewas wellicht goed kan worden toegepast in zilte gebieden in Nederland.

Vanaf begin $20^{\circ}$ eeuw werd geëxperimenteerd met sorghum als voedergewas en vanaf 2005 ook in Nederland. Het ziet er naar uit dat sorghum als voedergewas goed produceert op de drogere gronden, omdat het efficiënt omgaat met water en stikstof. Het gewas levert in tegenstelling tot snijmaïs veel ondergrondse biomassa, die door het diepgaande wortelstelsel bijdraagt aan een gezonde bodem met een hogere porositeit en een hoge C-vastlegging. De uitdaging is om - naast de genoemde voordelen van sorghum - gewassen te veredelen die qua kuilfermentatie, voederwaarde, voeropname en dierprestaties vergelijkbaar zijn met snijmaïs. Echter, de veredeling op de lange-dag-tolerantie in combinatie met koudetolerantie voor de jonge plant en de periode vanaf de bloei beperkt zich op dit moment nog tot enkele generaties, terwij I snijmaïs voor deze eigenschappen zeker 50 jaar voorsprong heeft.

Gerrit Kasper, onderzoeker 


\section{Samenvatting}

Dit literatuuronderzoek bespreekt het belang van sorghum wereldwijd en in het bijzonder voor Nederland. Sorghum behoort tot de vijf belangrijkste graangewassen in de wereld. Wereldwijd wordt ca. 58,6 miljoen ton ( $=58,6 \mathrm{M}$ ton) sorghumgraan geproduceerd. De belangrijkste productieregio's produceren 76\% hiervan: VS en Zuid Amerika (20 M ton), Afrika (13 M ton), Zuidoost Azië ( $10 \mathrm{M}$ ton) en Australië ( $1 M$ ton). De Europese productie is ongeveer 0,3 $M$ ton. Het gewas speelt een essentiële rol in het levensonderhoud op kleine boerderijen in Afrika en Azië. Als voedergewas is sorghum vooral van betekenis in Zuid-Amerika. In Europa is kennis over het voedergewas met melkvee vooral opgedaan in Frankrijk en Italië, waar het gewas is onderzocht op opbrengst, voederwaarde inclusief dierprestaties. In Italië is daarnaast gekeken naar het effect van sorghum op broeikasgasemissies en melksamenstelling.

Doelstelling van dit onderzoek is het inventariseren van aspecten op het gebied van bodem, ras en teelt van sorghum als voedergewas in Noordwest-Europa met de nadruk op Nederland, waarbij ook voederwaarde en dierprestaties worden meegenomen en vergeleken met die van snijmaïs.

Sorghum als voedergewas kan in twee typen worden onderscheiden: een type dat lijkt op gras (Sorghum Sudan) en een type dat zowel groen blad als graan bevat (Sorghum bicolor). Sorghum kan op alle gronden groeien waar ook snijmaïs het goed doet, bij voorkeur met een pH van 6,5 tot 8 . Het gewas kan in korte tijd veel voedingsstoffen opnemen, ook op armere en droge gronden. Dat betekent dat sorghum efficiënt omgaat met voedingsstoffen - vooral stikstof - en water. In het gematigde klimaat van Noordwest-Europa moet vooral rekening worden gehouden met de zaaiperiode, de kans op vorst tijdens bepaalde groeifasen (kieming, jonge plant en periode vanaf de bloei), en voldoende afrijping in het najaar. Plagen en ziekten bij sorghumteelt in (sub)tropische regio's treden in Noordwest-Europa in veel mindere mate of in het geheel niet op. Bovendien is sorghum geen gastheer voor de maïswortelboorder. Vanaf 2005 is een kweker in Nederland ( $51^{0}$ noorderbreedte) begonnen met het veredelen van sorghum - een eerste genetische aanpassing aan een hogere breedtegraad door ouderlijnen met elkaar te kruisen en de nakomelingen te selecteren voor lokale aanpassing (lange dag, koele weersomstandigheden). In 2016 resulteerde dit in een proefveldonderzoek van zeven verschillende rassen die vergeleken zijn met een snijmaïsras. Zes rassen waren afkomstig van de Nederlandse veredelaar (vijf hybriden en één lijn Sorghum bicolor) en het zevende ras was een Franse hybride (Vegga). De jaaropbrengsten van sorghum varieerden van 15 tot 20 ton ds/ha tegen 16 ton ds/ha bij snijmaïs. De drogestofgehalten varieerden van 30-35\% ds. Het ruw-eiwitgehalte van de sorghumrassen (behalve Vegga) was $8-13 \%$ hoger en de zetmeelgehalten tot $24 \%$ hoger dan die van snijmaïs. De verteringscoëfficiënten van de organische stof van alle sorghumrassen lagen echter lager (2-5\%) dan die van snijmaïs. In hoeverre de genoemde resultaten van de onderzochte sorghumrassen in Nederland een voldoende basis zijn om sorghumteelt te starten in de melkveehouderij is nog onduidelijk. Lopend onderzoek op praktijkpercelen moet daarover meer uitsluitsel geven. Bij positieve resultaten kan sorghumteelt als tussenteelt van een continuteelt snijmaïs interessant zijn evenals nieuwe combinatieteelten, b.v. wintergerst, winterrogge en andere combinaties met oogst voor eind juni (bedoeld als voedergewas) gevolgd door sorghum. Deze opties leveren niet alleen hogere drogestofopbrengsten met hogere eiwitgehalten, maar dragen ook positief bij aan de bodemvruchtbaarheid (o.a. C-vastlegging) en waarschijnlijk ook aan het verlagen van de mycotoxinendruk van ingekuilde sorghum ten opzichte van ingekuilde snijmaïs.

De belangrijkste kennishiaten voor onderzoek van sorghum in Nederland zijn:

- voederwaardering sorghum: het ontbreekt voornamelijk aan gegevens over de (darm) verteerbaarheid en de afbreekbaarheid in de pens.

- melkveehouders vragen concrete cijfers van praktijkpercelen (o.a. drogestofopbrengsten), maar ook voederwaardering, voeropname, mycotoxinendruk en dierprestaties van ingekuilde sorghum.

- $\quad$ het bepalen van broeikasgasemissies inclusief C-vastlegging in, en erosie van de bodem.

- de potentiële mogelijkheden en voordelen van sorghum zouden getoetst moeten worden in de praktijk bij éénmalige teelt van sorghum, bij teelt van twee gewassen (bijv. winterrogge en sorghum) en als tussenteelt van continuteelt (snij)maïs. 


\section{Summary}

This literature research discusses the importance of sorghum worldwide and especially for the Netherlands. Sorghum is one of the five most important cereals in the world. Worldwide, 58.6 million tonnes (= 58.6 M tonnes) sorghum grain are produced. The main production regions produce $76 \%$ of these: US and South America (20 M tonnes), Africa (13 M tonnes), South East Asia (10 M tonnes) and Australia ( $1 \mathrm{M}$ ton). The European production is about $0.3 \mathrm{M}$ ton. The crop plays an essential role on smallholder farms in Africa and Asia. Sorghum as a fodder crop is especially important in South America. In Europe, most research data on the use of sorghum as dairy cattle feed originate from France and Italy, where the crop has been evaluated for yield, feeding value including animal performance. In Italy, the effects of sorghum on greenhouse gas emissions and milk composition also have been studied.

The purpose of this research is to explore the potential of sorghum as a fodder crop in North West Europe with emphasis on the Netherlands, including feed and animal performance, compared to those of maize.

Sorghum as a fodder crop can be distinguished in two types: a type that resembles grass (Sorghum Sudan) and a type that contains both green leaf and grain (Sorghum bicolor). Sorghum can grow on all soils where maize also grows well, preferably with a $\mathrm{pH}$ of 6.5 to 8 . The crop can quickly absorb a lot of nutrients, even on rather poor and dry soils. This means that sorghum is efficiently dealing with nutrients, especially nitrogen and water. In the temperate climate of North West Europe, especial attention must be taken to the seeding period (germination, young plant and period from bloom), the chance of frost during certain growth phases, and sufficient ripening in the autumn. Pests and diseases in sorghum cultivation in (sub)tropical regions do not occur in North West Europe at all, or to a much lesser degree. In addition, sorghum is not a host to the maize root borer.

Since 2005, a breeder in the Netherlands ( $51^{\circ}$ nothern latitude) has started breeding sorghum, a first genetic adjustment to a higher latitude, by crossing parental lines and select offspring for local adaptation (long day, cool weather). In 2016, this resulted in a seven-breed field comparison with a maize variety. Six breeds came from the Dutch breeder (five hybrids and one line Sorghum bicolor) and the seventh breed was a French hybride (Vegga). The yields per year of sorghum ranged from 1520 tons DM/ha versus 16 tons DM/ha in maize. The DM-levels ranged from $30-35 \%$. The raw protein content of the sorghum varieties (except Vegga) was 7-13\% higher and the starch levels were up to $24 \%$ higher than these levels in maize. However, the digestibility coefficients of organic matter of all sorghum varieties were lower (ca. $5 \%$ ) than those in maize.

It is still unclear to what extent the aforementioned results of the examined sorghum breeds in the Netherlands are a sufficient basis for starting sorghum cultivation in dairy farming. Running applied research will give more clarity. If results are favourable, sorghum cultivation could be interesting as an intermediate crop in monoculture maize cropping systems, as well as the cultivation of winter rye or winter barley, and other combinations with harvest before end June (intended for fodder crops) followed by sorghum. These options do not only result in higher dry matter yields with higher protein levels, but also contribute to soil fertility (e.g. carbon sequestration) and also likely to reduce mycotoxin pressure of fermented sorghum in comparison to (fermented) maize.

The most important knowledge gaps of sorghum in the Netherlands are:

- feeding value of sorghum: data mainly lacks about digestibility and degradability in the rumen.

- dairy farmers ask concrete figures from practical plots (such as dry matter yields), but also feed value, feed intake, mycotoxin pressure and animal performance of ensiled sorghum.

- determining greenhouse gas emissions included C-sequestration in, and erosion of the soil.

- the potential possibilities and benefits of sorghum should be evaluated in practice as a single crop, as a cultivation of two crops (e.g. winter rye and sorghum) and as an intermediate cultivation to interrupt the monoculture of maize growing. 


\section{$1 \quad$ Inleiding}

Sorghum behoort tot de vijf belangrijkste graangewassen ter wereld. Het gewas is van cruciaal belang voor het levensonderhoud op kleine boerderijen met lage input-condities van een aantal landen in Afrika en Azië.

Vanaf 1920 is sorghum ook als voedergewas toegepast in Tsjechië als eerste land in Europa. In 1950 was het areaal van dit gewas groter dan dat van de nieuwe variëteiten van maïs (Hermuth et al., 2016). Op dit moment wordt het als voedergewas geteeld in Frankrijk (Hermuth et al., 2016; Emile et al., 2006), I talië (Tabacco et al., 2011; Cattani et al., 2017) en Hongarije (Kálmán et al., 2016; Kovács, 2014), Oostenrijk, Spanje en Roemenië ( $1^{\text {ste }}$ European Sorghum Congress, 2016). Sinds de $21^{\text {e }}$ eeuw is er ook belangstelling vanuit Duitsland (Mahmood, 2012; Zeise et al., 2014) en Oostenrijk (Theuretzbacher et al., 2012) om het als co-product voor mestvergisting te gebruiken. Een overzicht van sorghumteelt in Europese landen met bijbehorende arealen en producties per hectare is gegeven door Berenji et al. (2004). Dit overzicht laat o.a. zien dat in 2004 in Europa minder dan 0,5\% van de totale wereldproductie sorghum wordt geteeld.

Sinds 2005 is er belangstelling voor sorghumteelt in Nederland. De eerste vraag was of onder Nederlandse omstandigheden kiemkrachtig zaad zou kunnen worden geproduceerd. Een kweker in Zuid-Nederland startte met een paar uitgangslijnen die gekruist werden. De voederwaarden van de ontstane hybriden toonden veel perspectief, in die zin dat de verteringscoëfficiënt van de organische stof en het zetmeel plus suikergehalte gelijk waren aan die van snijmaïs (Van Eekeren et al., 2014). In een later onderzoek, uitgevoerd in 2015, bleken graanopbrengsten van 5 ton/ha/jaar en ruwvoeropbrengsten van 20 ton ds/ha/jaar haalbaar in Nederland (De Wit et al., 2016). Uit dit onderzoek waren al duidelijke lijnen voor graanproductie en voor veevoerproductie te herkennen. Dit opent mogelijkheden om het gewas op te nemen als derde voedergewas - naast gras en snijmaïs - in de Nederlandse veehouderij. Buiten de landbouw is er in Nederland al belangstelling voor sorghum.

Momenteel onderzoekt het bedrijf NewFoss te Boekel (Nederland) welke interessante componenten uit bladeren en stengels perspectief hebben. Het Prinsen College in Bergen op Zoom onderzoekt de zaden als mogelijkheid voor de productie van glutenvrij bier.

In dit literatuuronderzoek zal verder worden ingegaan op mogelijkheden van de Nederlandse melkveehouderij waarbij rassenkeuze, teeltaspecten (zaaidatum, zaaidichtheid, bemesting, afrijping, voederwaarde, stressfactoren) van sorghum aan de orde komen, onder optimale en niet-optimale omstandigheden.

\section{$1.1 \quad$ Doel}

Doel van deze studie is het inventariseren van aspecten op het gebied van bodem, ras en teelt van sorghum als rundveevoeder, waarbij mogelijk ook voederwaarde, en dierprestaties - voeropname en melkgift - meegenomen worden.

\subsection{Leeswijzer}

In hoofdstuk 2 wordt een aantal aspecten van de sorghumteelt besproken, zoals ziekten en plagen, milieuomstandigheden, productie en voederwaarde. Hoofdstuk 3 handelt over de toepassing van sorghum als veevoeder wereldwijd maar ook in de EU en Nederland. Naast de genoemde aspecten wordt ook aandacht besteed aan bodemgezondheid in relatie tot de teelt van snijmaïs. Mogelijkheden van sorghum als veevoeder in Nederland komen in hoofdstuk 4 aan de orde. Hoofdstuk 5 geeft de conclusies en aanbevelingen weer. 


\section{Sorghumteelt}

\section{$2.1 \quad$ Verschijningsvorm}

Sorghum is een C4-gewas dat goed groeit onder subtropische en tropische omstandigheden. Informatie over het ontstaan en de verspreiding van het gewas wereldwijd is vermeld in Windpassinger (2016). De verscheidenheid in klimaat en bodem, en de selectie voor verschillende toepassingen (graan, veevoeder, suiker en vezel) heeft geleid tot een enorme morfologische en genetische variatie die nog niet volledig is benut. Sorghum bicolor bijvoorbeeld omvat vijf rassen die alle verschillende bloeiwijzen (pluimen) laten zien (figuur 1). Rassen met een open pluim zijn aangepast aan het vochtige klimaat waar ze groeien. De rassen met gesloten pluimen worden geteeld in gebieden met een droger klimaat. De hoogtes van de rassen variëren van $0,5 \mathrm{~m}$ tot ruim $5 \mathrm{~m}$. Echter, bij graanrassen wordt gestreefd naar lengtes van hooguit 1,80 $\mathrm{m}$ om het oogsten met een combine mogelijk te maken.
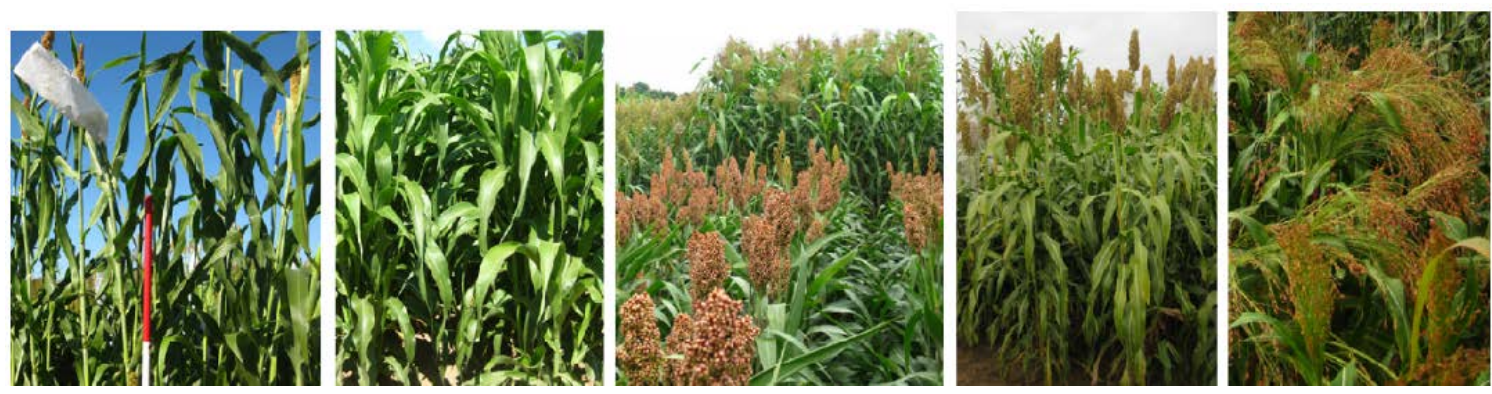

Figuur 1 Verschillende gewastypen van sorghum. Van links naar rechts: sweet type met dikke stengels, bladachtige voedertype, kort graansorghum (vooraan) met daarachter het hoge vezelsorghum, vroegrijpe silage-type of dual-use type, broomcorn (bron: Windpassinger, 2016).

\subsection{Milieuomstandigheden}

Een plant kan stress ervaren door milieuomstandigheden, bijvoorbeeld veranderingen in temperatuur, vochtvoorziening, voedingsstatus, mineralentekort of mineralenoverschot. Daarom moet rekening gehouden worden met de range waarbinnen een plant goed groeit.

Sorghum kan geteeld worden op de meeste bodemtypen met bij voorkeur een pH tussen 6 en 8,5. Er zijn echter uitzonderingen: in Sierra Leone groeit sorghum op gronden met een $\mathrm{pH}$ van 4 . Omdat het gewas van origine een tropische plant is, verdraagt het geen vorst. Vooral de kieming en opkomst zijn cruciaal in gematigde gebieden, zoals Noordwest-Europa. Daarom is het aan te bevelen om sorghum in de periode van 15 mei tot begin juni te zaaien. Het gewas vereist bodemtemperaturen boven de $12^{\circ} \mathrm{C}$ en groeit goed bij temperaturen boven de $20^{\circ} \mathrm{C}$. Lagere temperaturen geven een niet-optimale groei, niet alleen vanwege een slechtere kieming en opkomst van de plant, maar ook tijdens de bloeiperiode. Lage nachttemperaturen kunnen de vruchtbaarheid van pollen reduceren (Osuna-Ortega, 2003). Echter, ook hittestress kan tijdens de bloei nadelige effecten hebben op de zaadvorming bij temperaturen boven de $36-38^{\circ} \mathrm{C}$ (Singh et al., 2015). Gelukkig is er diversiteit in koudetolerantie, wat mogelijkheden biedt voor veredeling voor hoger gelegen regio's en hogere breedtegraden. Sorghum is een C4-plant evenals bijvoorbeeld (snij)maïs, maar gaat veel efficiënter om met water (Reddy et al. 2011; Premachandra et al., 1994; Singh et al., 2010; Robertson et al., 1993 ). Ze is goed bestand tegen veel regen en goed aangepast aan hoge zonnestraling en hoge temperaturen. Wateroverlast vertraagt echter de groei. Het gewas heeft een groot vermogen om voedingsstoffen op te nemen (Rehm \& Espig 1996) waardoor een goede groei op arme bodems mogelijk is. Voorts toont het een hogere efficiëntie van stikstofopname (Nutrient Use Efficiency= NUE) dan (snij)maïs, vooral bij een lage $\mathrm{N}$-beschikbaarheid in de bodem (Young et al., 2000). Een verklaring hiervoor is de diepere beworteling van sorghum dan die van maïs $(200 \mathrm{~cm}$ versus 30 tot $100 \mathrm{~cm}$; Celano et al., 2012). De 
hogere NUE van sorghum geeft ook aan dat dit gewas beter groeit onder droge omstandigheden dan snij(maïs). Daarnaast heeft sorghum een hoge zouttolerantie (Almodares et al. 2008).

\subsection{Ziekten en plagen}

Sorghum heeft vooral in tropische en subtropische gebieden te lijden onder ziekten en plagen en ondervindt daardoor stress. Ziekteverwekkers en onkruiden zijn hiervoor verantwoordelijk.

De zogenaamde 'sorghum valse meeldauw' (Eng.: downy mildew) is wellicht de meest schadelijke schimmelziekte in deze gebieden, omdat het de groei sterk vermindert en door zijn systemische werking zelfs desastreus kan zijn. Andere schimmels kunnen, afhankelijk van de mate van besmetting, door plekken op bladeren of op stengels grote opbrengstverliezen geven (Sleper \& Poehlman, 2006). Bepaalde schimmels kunnen in meer of mindere mate mycotoxinen vormen. Van sorghum in India is bekend dat tijdens de teeltperiode de schimmel Fusarium moniliforme onder bepaalde omstandigheden fumonisine als mycotoxine vormt, die ziekten bij mens en dier kan veroorzaken (Bhat et al., 1997). Ook in Nigeria werden mycotoxinen van Fusarium gevonden in sorghum, maar vergeleken met andere gewassen zoals maïs, millet en ogi, in een lagere hoeveelheid, respectievelijk 44\% vs 77\%, 59\%, 97\% (Chilaka et al., 2016). Dit onderzoek had betrekking op graankorrels die bestemd waren voor humane voeding. In Uruguay is het gehalte van mycotoxinen in sorghumsilage onderzocht dat bestemd was voor melkveevoeding. Het bleek dat de meest voorkomende schimmels Penicillium spp. (70\%), Aspergillus spp. (65\%), Absidia spp. (40\%), Fusarium spp. (35\%), Paecilomyces spp. (35\%) en Alternaria spp., Cladosporium spp., Gliocadium sp. en Mucor sp. (30\%) waren, met als meest voorkomende soorten: Penicillium citrinum, Aspergillus flavus en Fusarium nygamai. Sorghumsilage wordt gebruikt in enkele Europese landen, waarbij literatuur over de aanwezigheid van mycotoxinen in deze silage ontbreekt.

Wat betreft plagen zijn een bladluis (Eng.: 'greenbug' = Schizaphis graminum) en 'sorghum mug' (Contarinia sorghicola) het meest verbreid en schadelijk. De parasitaire onkruiden Striga hermonthica en Striga asiatica kunnen sorghum infecteren door de plant bij de wortel aan te vallen. Hierdoor kan de water- en nutriëntenaanvoer volledig verstoord worden waardoor de plant afsterft. Door veredeling zijn sorghumvariëteiten ontstaan die verschillende resistentiemechanismen hebben tegen de Strigasoorten of de stof sorgoleone - die de groei van Striga bevordert - en waardoor selecties met een lage hoeveelheid kiemingsstimulatie minder vatbaar (= resistent) zijn voor deze onkruiden dan selecties met een hoge hoeveelheid kiemingsstimulatie. In gematigde gebieden, zoals Europa, treden deze plagen en ziekten in mildere vorm op of zijn in het geheel niet aanwezig en sommige ziekteveroorzakers zijn quarantaine-organismen. De 'sorghum valse meeldauw' is nog onbekend, de bladluis 'greenbug' en de 'sorghum mug' komen niet voor (Williams et al., 1980, De Milliano et al., 1992, Leslie, 2002, Berenji \& Dahlberg, 2004). Bovendien is sorghum geen gastheer voor de maïswortelboorder of maïswortelkever (Diabrotica virgifera; Oyediran et al. 2004), die de wortels van (snij)maïs aantast en grote schade veroorzaakt. 


\subsection{Productie en voederwaarde}

In figuur 2 is de top 10 van landen weergegeven waar de hoogste graanproducties van sorghum worden behaald.

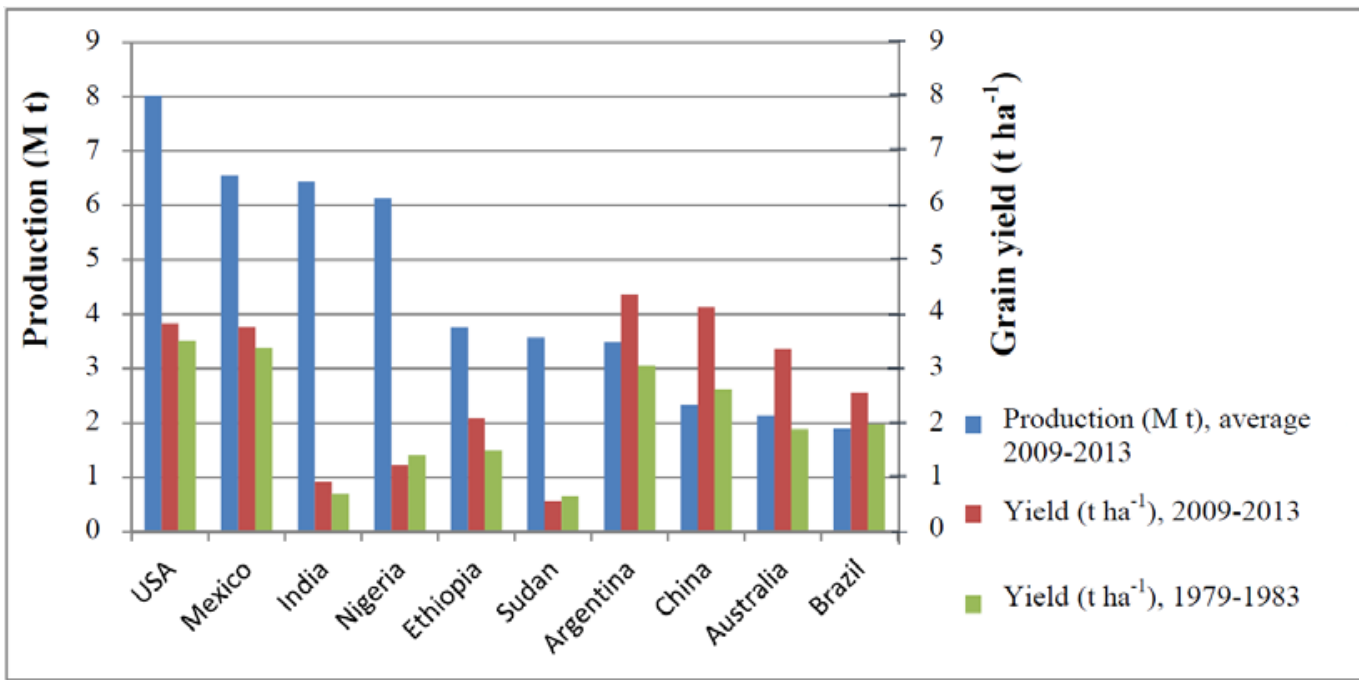

Figuur 2 Totale sorghum-graanproductie (in miljoen ton (=M ton); gemiddelde van 2009-2013) en sorghum-graanopbrengst per hectare ten opzichte van 1979-1983 van de top 10 van sorghumgraan producerende landen (bron: Windpassinger, 2016).

Wereldwijd wordt 58,6 miljoen ton (= 58,6 M ton) graansorghum geproduceerd (Windpassinger, 2016). De productie van de landen genoemd in figuur 2 is goed voor $76 \%$ van de wereldgraanproductie van sorghum (Windpassinger, 2016). Globaal betekent dit: VS en Zuid Amerika (20 M ton), Afrika (13 M ton), Zuidoost Azië (10 M ton) en Australië (1 M ton). De Europese productie is ongeveer 0,3 M ton. De hoogst producerende landen - de VS, Mexico, Argentinië, China en Australië - produceren ca. 4 ton graan/ha/jaar. Opgemerkt moet worden dat sorghum meestal geteeld wordt op marginale gronden, die te droog zijn voor maïs en tarwe. De potenties van het gewas zijn echter enorm. In Texas (VS) worden onder optimale omstandigheden producties van 20 ton graan/ha/jaar en 80 ton ds/ha/jaar aan biomassa gerealiseerd. Daarentegen zijn de opbrengsten in India en een aantal Afrikaanse landen laag, ca. 1 ton ds/ha/jaar. De sorghum wordt hier geconsumeerd door de gezinnen van kleine boerenbedrijven.

Van de wereldproductie wordt $80 \%$ van sorghum als ruwvoer geproduceerd in de VS, Mexico en Argentinië (Windpassinger, 2016). In Nederland is sinds 2005 onderzoek gedaan naar sorghumrassen met het doel te testen of zaadproductie mogelijk is (Van Eekeren en Deru, 2014). De opbrengsten in dit onderzoek variëren van 9 tot 18 ton ds/ha/jaar (zie ook paragraaf 3.1.3). 


\section{Toepassing als diervoeder}

\subsection{Alternatief van maïs}

\subsubsection{Buiten de EU}

Wereldwijd wordt sorghum geteeld voor veevoeder en wordt ook ingekuild om als voer te dienen voor de perioden in het jaar met minder of geen ruwvoerproductie. In Argentinië wordt bijvoorbeeld het winnen van ruwvoer uit sorghum voor vleesvee gezien als een beter alternatief dan uit (snij)maïs. De redenen zijn dat (snij)maïs op armere gronden en onder droge omstandigheden onvoldoende opbrengt. Sorghum kan door zijn hoge hitte- en droogtetolerantie op deze gronden toch nog een hoge productie halen (Abdelhadi \& Tricarico, 2009). Ook in Israël is onderzoek gedaan met het doel maïs mogelijk te vervangen door sorghum. In dit land is water schaars; irrigatie wordt vaak toegepast. Het onderzoek gaat in op het selecteren van rassen met een hoge voederwaarde en hoge verteerbaarheid, omdat het verstrekt wordt aan melkvee met een hoge melkproductie. Moeilijk verteerbare delen van de plant verlagen de verteerbaarheid, zoals stengels met een hoog aandeel lignine. Daarom wordt aanbevolen de stengels maar deels te oogsten. Bij de selectie hoort ook een hoog aandeel zetmeel, dat aangetroffen wordt in de graankorrel. Tenslotte moet het goede tijdstip gekozen worden voor het optimale drogestofgehalte (Asbell \& Weinberg, 2000). In de Verenigde Staten (Georgia) zijn van maïs en sorghum twee oogsten per jaar (juli: corn silage-summer (CSS) en forage sorghum-summer (FSS); en november: corn silage-fall (CSF) en forage sorghum-fall (FSF)) onderling vergeleken (Bernard et al., 2015). Hierbij kan de tweede snede van sorghum worden geoogst zonder opnieuw te zaaien. De beide gewassen werden in april gezaaid. Doel van het onderzoek was om de melkproductie en melkgehalten te vergelijken. Al het ruwvoer was ingekuild in gesealde grote balen die bewaard werden tot het moment dat eruit gevoerd werd. In het onderzoek werd bij de rantsoensamenstelling 39\% van zowel de maïs- als de sorghumsilages nagestreefd.

De samenstelling van een aantal inhoudsstoffen van de ruwvoerders is weergegeven in tabel 1.

Tabel 1 Kenmerkende inhoudsstoffen van maïssilage (CS) en sorghumsilage (FS) voor de oogsttijdtippen zomer (S) en herfst (F), drogestofopnames van deze silages, melkproductie en vetgehalte. Ds $=$ drogestof, RE = ruw eiwit, NDF = neutral detergent fiber, $A D L=$ acid detergent lignin.

\begin{tabular}{|c|c|c|c|c|c|c|c|c|c|}
\hline $\begin{array}{l}\text { Silage- } \\
\text { type }\end{array}$ & $\begin{array}{l}\text { Ds } \\
(\%)\end{array}$ & $\begin{array}{r}\text { pH } \\
-\end{array}$ & $\begin{array}{r}\text { azijnzuur } \\
\mathrm{g} / \mathrm{kg} \text { ds }\end{array}$ & $\begin{array}{c}\text { RE } \\
\mathrm{g} / \mathrm{kg} \text { ds }\end{array}$ & $\begin{array}{c}\text { NDF } \\
\mathrm{g} / \mathrm{kg} \text { ds }\end{array}$ & $\begin{array}{c}\text { ADL } \\
\mathrm{g} / \mathrm{kg} \text { ds }\end{array}$ & $\begin{array}{l}\text { Ds opn. } \\
\mathrm{kg} / \mathrm{d} / \mathrm{d}\end{array}$ & $\begin{array}{l}\text { Melkpr } \\
\mathrm{kg} / \mathrm{d} / \mathrm{d}\end{array}$ & $\begin{array}{r}\text { Melkvet } \\
(\%)\end{array}$ \\
\hline CSS & 46,6 & 5,11 & 1,04 & 80 & 390 & 36 & 21,4 & 32,2 & 3,20 \\
\hline $\mathrm{CSF}$ & 29,6 & 3,95 & 1,98 & 85 & 383 & 28 & 23,1 & 33,4 & 2,91 \\
\hline FSS & 28,7 & 4,12 & 4,89 & 90 & 542 & 77 & 22,6 & 32,9 & 3,42 \\
\hline FSF & 29,7 & 4,45 & 5,18 & 95 & 551 & 78 & 21,1 & 33,5 & 3,53 \\
\hline
\end{tabular}

Tabel 1 laat zien dat het drogestofgehalte van CSS bij oogst in de zomer nogal hoger is dan van de andere drie kuilen. Dit verklaart ook de hogere pH van CCS. Verder zijn de gehalten aan azijnzuur, ruw eiwit, NDF en ADL bij de sorghumkuilen hoger dan van de maïskuilen. De drogestofopnames en melkproducties verschilden niet tussen de vier kuilvoeders. Wel waren de melkvetgehalten van koeien gevoerd met rantsoenen van de sorghumkuilen significant hoger dan die van de maïskuilen.

\subsubsection{Europa}

Zoals in de inleiding vermeld, wordt sorghum vrijwel niet geteeld in Europa. Wel is er onderzoek uitgevoerd naar sorghum als voedergewas ter vervanging van (snij)maïs op vooral droge en arme gronden om de opbrengstreductie van maïs te kunnen compenseren. Er zijn rassen onderzocht op productie en voederwaarde in Tsjechië (Dvorackova et al., 2013), in I talië (Cattani et al., 2017; Colombini et al., 2015) en in Frankrijk (Emile et al., 2006). Het onderzoek van Colombini et al. (2015) laat zien dat melkveehouders in de Po-vlakte intensieve bedrijven hebben met hoge melkproducties. 
Daarom is ruwvoer met een hoge voederwaarde vereist. Snijmaïs past daarin goed, maar sorghum minder door de lagere energie-inhoud. De opbrengsten van snijmaïs, graansorghum en foragesorghum zijn respectievelijk 15,4, 12,5 en 12,9 t ds/ha. Ondanks de lagere drogestofopbrengsten en lagere energiegehalten is er in Noord-Italië (Po-vlakte) toch een groeiende belangstelling voor sorghumteelt i.v.m. de meer milieuvriendelijke teelteigenschappen in vergelijking met snijmaïs, zoals lagere inputs van (kunst)mest en water, en een betere N-efficiëntie (Gardner et al, 1994). Hierbij speelt mee dat vanwege de hoge veebezetting voorzorgsmaatregelen gelden, onder andere maximaal $170 \mathrm{~kg} \mathrm{~N} / \mathrm{ha} / \mathrm{jaar}$ uit dierlijke mest voor het behouden van een goede waterkwaliteit (European Commission, 1991). De lagere energieopname uit sorghum wordt gecompenseerd door aankoop van meer krachtvoer (tabel 2).

Tabel 2 Opbrengsten, aandeel in het rantsoen, drogestofopname van het rantsoen en melkproductie uit het rantsoen.

\begin{tabular}{|c|c|c|c|c|c|c|}
\hline ruwvoergewas* & Opbrengst & $\begin{array}{l}\text { Ruwvoer } \\
\text { silage }\end{array}$ & $\begin{array}{l}\text { Maïsglu- } \\
\text { tenmeel }\end{array}$ & $\begin{array}{l}\text { SOM } \\
\text { rvs+mgm }\end{array}$ & $\begin{array}{l}\text { Drogestof- } \\
\text { opname }\end{array}$ & $\begin{array}{l}\text { Melk- } \\
\text { productie }\end{array}$ \\
\hline & $t d s /$ ha & $\%$ in rants. & $\%$ in rants. & $\%$ in rants. & kg ds/ dier/ dag & $\mathrm{Kg} /$ dier/ dag \\
\hline graansorghum & 12,5 & 36,7 & 21,3 & 58,0 & 20,0 & 24,6 \\
\hline forage-sorghum & 12,9 & 28,0 & 29,4 & 57,4 & 18,5 & 23,6 \\
\hline
\end{tabular}

* Het betreft hier het geoogste gewas of de silages van het gewas bij rantsoensamenstelling

Tabel 2 laat verder zien dat bij snijmaïssilage een groter aandeel in het rantsoen heeft dan de sorghumsilages. Bij de drie gewassen wordt maïsglutenmeel aangevuld tot ongeveer $58 \%$ van het rantsoen. De overige $42 \%$ van het rantsoen heeft vrijwel gelijke aandelen van andere componenten. De voeropname en melkproductie van het rantsoen met forage-sorghum was lager dan van de andere ruwvoeders. Het onderzoek van Colombini et al. (2015) was verder gericht op het vaststellen van de broeikasgasemissies van de drie gewassen voor de keten van "zaad tot boerderijpoort" LCA (cradle to farm-gate Life Cycle Assessment). Hierbij werden de emissies van de activiteiten op het bedrijf (ruwvoerproductie, verbruik van brandstof en elektriciteit, mest- en veemanagement), buiten het bedrijf (productie van kunstmest, pesticiden en ligbedmaterialen, aankoop van ruw- en krachtvoer, vervanging van dieren, elektriciteit en brandstof) en transport in beschouwing genomen. Hiervoor werd de $\mathrm{CH} 4$-emissie van zes $1^{\mathrm{e}}$ kalfsmelkkoeien geregistreerd in een respiratiekamer. De resultaten van het onderzoek gaven aan dat gedurende de teeltperiode de beide sorghumgewassen lagere emissies vertonen dan snijmaïs - door het lagere gebruik van kunstmest en water -, maar dat opname van sorghumsilages in het rantsoen nadelig uitpakt voor de broeikasgasemissies doordat er meer krachtvoer (maïsglutenmeel) moest worden opgenomen om een evenwichtig rantsoen te realiseren. Cattani et al. (2017) onderzochten het effect van totale vervanging van snijmaïssilage door sorghumsilage in het rantsoen op melkproductie, melkgehalten en melksamenstelling. Geen verschillen werden geconstateerd in melkhoeveelheid (gecorrigeerd naar $4 \%$ vet) en melksamenstelling (vetzurenprofiel en coagulatie-eigenschappen). Wel was het melkvetgehalte significant hoger.

In het Franse onderzoek is de teelt van snijmaïs en twee sorghumsilages (Sorghum bicolor L.), graansorghum en forage-sorghum, met elkaar vergeleken onder droge omstandigheden. De opbrengsten waren respectievelijk 20,1, 14,3, 17,8 en t ds/ha (tabel 3). De gemeten hoeveelheden neerslag tijdens het groeiseizoen waren resp. 191, 174 en $190 \mathrm{~mm}$. Echter, aan snijmaïs werd van begin juli tot half augustus in vijf giften $152 \mathrm{~mm}$ extra vocht gegeven middels irrigatie. De ruweiwitpercentages waren van de graansorghum en forage-sorghum resp. $27 \%$ en $16 \%$ hoger dan die van snijmaïs. De som van de gehaltes zetmeel en suikers was voor de drie gewassen vergelijkbaar. 
Tabel 3 Watergift en voederwaarden van snijmaïs, graansorghum en forage-sorghum (bron: Emile et al., 2006, gewijzigd).

\begin{tabular}{|c|c|c|c|c|c|c|}
\hline behandeling & $\begin{array}{l}\text { neerslag + } \\
\text { irrigatie } \\
\mathrm{mm}\end{array}$ & $\begin{array}{r}\text { drogestof- } \\
\text { opbrengst } \\
\text { t ds/ ha }\end{array}$ & $\mathrm{g} / \mathrm{kg}$ ds & $\mathrm{g} / \mathrm{kg}$ ds & $\mathrm{g} / \mathrm{kg}$ ds & $\begin{array}{r}\text { wateropl. } \\
\text { suikers } \\
\text { g/ kg ds }\end{array}$ \\
\hline snijmaïs & $191+152$ & 20.1 & 82 & 390 & 304 & 41 \\
\hline graansorghum & $174+0$ & 14.3 & 104 & 400 & 277 & 46 \\
\hline forage-sorghum & $190+0$ & 17.8 & 95 & 383 & 296 & 46 \\
\hline
\end{tabular}

\section{Teeltkosten}

De teeltkosten van de drie gewassen, snijmaïs, graansorghum en forage-sorghum zijn weergegeven in tabel 4. In het kostenoverzicht zijn de mechanisatiekosten, arbeidskosten - i.v.m. irrigatie en pesticiden (frequenter spuiten) - en vaste kosten niet meegenomen. Dit betekent dat er geen financieringskosten - rente, afschrijving en onderhoudskosten - voor de elektrapomp zijn berekend.

Tabel 4 Kosten van snijmaïs, graansorghum en forage-sorghum (in euro/ha, bron: Emile et al., 2006).

\begin{tabular}{lrrrrr} 
behandeling & kunstmest & zaden & pesticiden & elektr. energie* & Totaal \\
snijmaïs & 97 & 158 & 177 & 76 & 508 \\
\hline graansorghum & 59 & 99 & 129 & 0 & 287 \\
\hline forage-sorghum & 59 & 51 & 129 & 0 & 239 \\
\hline
\end{tabular}

* energie nodig voor irrigatie

Tabel 4 laat zien dat de teelkosten van snijmaïs $€ 221 /$ ha/jaar en $€ 269 /$ ha/jaar hoger zijn dan voor graansorghum en forage-sorghum.

\subsubsection{Nederland}

Na drie jaar gericht onderzoek door een kweker in Zeeuws-Vlaanderen (De Milliano) is een aantal lijnen ontwikkeld waarmee gekruist werd. Nadat bleek dat er daadwerkelijk nieuw materiaal geproduceerd was uit deze kruisingen, is nog een aantal generaties geteeld om zuivere lijnen te maken. Deze lijnen zijn in 2015 vergeleken met commercieel beschikbare sorghumrassen in Europa en met snijmaïs (tabel 5).

Tabel 5 Opbrengsten en voederwaarde van negen verse sorghumrassen in vergelijking met snijmaïs (bron: Van Eekeren en Deru, 2014).

\begin{tabular}{|c|c|c|c|c|c|c|c|c|c|}
\hline Ras* & bedrijf** & $\begin{array}{l}\text { Droge- } \\
\text { stof }\end{array}$ & $\begin{array}{l}\text { Op- } \\
\text { brengst }\end{array}$ & $\begin{array}{l}\text { vcos } \\
\text { NIRS }\end{array}$ & $\begin{array}{l}\mathrm{v} \cos * * * \\
\text { T\&T }\end{array}$ & ruw eiwit & suiker & zetmeel & $\begin{array}{l}\text { suiker + } \\
\text { zetmeel }\end{array}$ \\
\hline & & ds $\%$ & ds/ ha & $\%$ & $\%$ & $\mathrm{~g} / \mathrm{kg}$ ds & $\mathrm{g} / \mathrm{kg}$ ds & $\mathrm{g} / \mathrm{kg}$ ds & $\mathrm{g} / \mathrm{kg}$ ds \\
\hline Piper & American & 27 & 9,3 & 66 & 60 & 118 & 97 & 89 & 186 \\
\hline Sole & KWS & 36 & 14,8 & 66 & 60 & 93 & 64 & 212 & 276 \\
\hline Bovital & Saaten Uni. & 32 & 8,6 & 69 & 63 & 98 & 100 & 163 & 263 \\
\hline Sweet Cal. & Barenbrug & 22 & 13,2 & 81 & 79 & 91 & 233 & 98 & 331 \\
\hline Zerberus & KWS & 29 & 17,4 & 71 & 64 & 85 & 190 & 35 & 225 \\
\hline L3 & Hoeve Dierk & 35 & 13,0 & 71 & 68 & 84 & 120 & 186 & 306 \\
\hline L7 & Hoeve Dierk & 38 & 18,2 & 75 & 72 & 95 & 113 & 264 & 377 \\
\hline L8 & Hoeve Dierk & \multicolumn{8}{|c|}{ gelegerd, geen metingen } \\
\hline L11 & Hoeve Dierk & 28 & 12,0 & 72 & 69 & 105 & 141 & 170 & 311 \\
\hline Snijmaïs & Innoseeds & 30 & 20,3 & 74 & & 70 & 84 & 251 & 335 \\
\hline
\end{tabular}

* Sweet Cal. = Sweet California

** American = American Genetic Inc., Saaten Uni. = Saaten Union, Hoeve Dierk = Hoeve Dierkensteen

$* * *$ VCOS T\&T $=$ VCOS Tilly $\&$ Terry 
Tabel 5 laat zien dat de opbrengsten van alle sorghumrassen achter blijven bij die van snijmaïs (vaak eerder gezaaid dan sorghum). De rassen Zerberus (hybride) en L7 (lijn) komen het dichtst in de buurt. Sweet California (hybride) heeft een hoge VCOS, zelfs hoger dan snijmaïs. Het suiker- en zetmeelgehalte van dit ras is gelijk aan die van snijmaïs. Wel is het zetmeelgehalte relatief laag. Dit betekent dat het gewas niet voldoende is afgerijpt, wat ook te zien is aan het lage drogestofgehalte. Het eiwitgehalte van alle sorghumrassen was $20 \%$ tot $69 \%$ hoger dan van snijmaïs. Hoewel er sorghumrassen voor veevoeder geproduceerd worden in Zuid-Frankrijk en Zuid-Duitsland, zijn deze rassen niet geschikt voor Nederland, omdat ze in Nederland niet voldoende kunnen afrijpen.

Onderzoek in 2015 op twee locaties in Nederland, Oostburg (klei) en Strijen (zand), - waarbij zeven nieuwe lijnen van de kweker De Milliano zijn getest - toont dat opbrengsten van 5 ton graan en 20 ton droge stof per hectare haalbaar lijken (De Wit \& Van Eekeren, 2016). Uit dit onderzoek zijn zowel lijnen te selecteren voor graanproductie als voor veevoederproductie. De lijnen die geschikt zijn voor veevoeder moeten naast blad en stengel ook een relatief hoog graanaandeel hebben om de hoeveelheid suiker en zetmeel zeker te kunnen stellen, vergelijkbaar aan die van snijmaïs. Knelpunten uit dit onderzoek zijn de grote opbrengstverschillen, veroorzaakt door ras (lijn, hybride), zaaitijdstip, grondsoort, bemestingsniveau, zaaidichtheid en zaaduitval.

In 2016 zijn in België en Nederland zeven sorghumrassen met één snijmaïsras vergeleken (Van de Goor et al., 2017). Op 27 april 2016 werd in de rij $35 \mathrm{~m}^{3}$ rundveedrijfmest/ha (samenstelling: 4,01 kg $\mathrm{N} /$ ton; $1,74 \mathrm{~kg} \mathrm{P} \mathrm{O}_{5} /$ ton; 5,7 kg K${ }_{2} \mathrm{O} /$ ton) toegediend per ras. Op 17 mei 2016 werd kunstmest breedwerpig toegediend: $100 \mathrm{~kg} \mathrm{~N} /$ ha uit KAS en $100 \mathrm{~kg} \mathrm{~K}{ }_{2} \mathrm{O} / \mathrm{ha}$. Door het natte voorjaar van 2016 waren de proefomstandigheden niet ideaal en was er veel variatie in opkomst bij zowel maïs als sorghum. De resultaten van de proef in Nederland zijn weergegeven in tabel 6.

Tabel 6 Opbrengst en voederwaarde op locatie Boekel (Nederland; bron: Van de Goor et al., 2017).

\begin{tabular}{|c|c|c|c|c|c|c|c|c|c|}
\hline Behandeling & $\begin{array}{l}\text { ds } \\
(\%)\end{array}$ & $\begin{array}{l}\text { opbrengst } \\
\text { t ds/ ha }\end{array}$ & $\begin{array}{l}\text { ruweiwit } \\
\text { g/ kg ds }\end{array}$ & $\begin{array}{l}\text { Vcos } \% \\
\text { (NIRS) }\end{array}$ & $\begin{array}{r}\text { vcos } \% \\
\text { (T\&T) }\end{array}$ & $\begin{array}{l}\text { suiker } \\
\text { g/ kg ds }\end{array}$ & $\begin{array}{l}\text { zetmeel* } \\
\text { g/ kg ds }\end{array}$ & $\begin{array}{l}\text { zetmeel** } \\
\qquad \mathrm{g} / \mathrm{kg} \text { ds }\end{array}$ & $\begin{array}{l}\text { ADL } \\
\text { g/ kg } \\
\text { ds }\end{array}$ \\
\hline Snijmaïs & 35,4 & 15,8 & 71 & 76,5 & 76,0 & 65 & 329 & 330 & 18 \\
\hline${ }^{1} \mathrm{C} 72.0$ & 33,3 & 14,6 & 80 & 73,6 & 72,2 & 29 & 448 & 402 & 21 \\
\hline${ }^{2} \mathrm{C} 72.75$ & 34,1 & 15,3 & 77 & 73,8 & 73,3 & 26 & 439 & 440 & 21 \\
\hline${ }^{1}$ Vegga 2.0 & 27,2 & 17,2 & 77 & 76,4 & 72,3 & 107 & 279 & 277 & 21 \\
\hline${ }^{2}$ Vegga 2.75 & 31,1 & 16,5 & 66 & 76,6 & 74,0 & 94 & 289 & 283 & 20 \\
\hline HDD- 1 & 32,8 & 15,5 & 78 & 73,4 & 71,8 & 25 & 407 & 381 & 21 \\
\hline HDD-2 & 31,5 & 19,7 & 76 & 75,3 & 72,5 & 26 & 470 & 423 & 20 \\
\hline HDD-3 & 32,9 & 20,1 & 78 & 74,5 & 71,9 & 28 & 441 & 402 & 22 \\
\hline HDD-4 & 31,3 & 18,0 & 76 & 72,3 & 66,6 & 29 & 345 & 299 & 24 \\
\hline HDD- 5 & 30,6 & 19,4 & 76 & 70,7 & 65,5 & 26 & 339 & 275 & 25 \\
\hline
\end{tabular}

* bepaling via de NIRS-methode; ** bepaling via de klassieke methode (Tilly\&Terry)

${ }^{1} 2.0$ betekent 200.000 planten per ha; ${ }^{2} 2.75$ betekent 275.000 planten per ha

Tabel 6 laat zien dat de opbrengsten van sorghum variëren van 15 tot 20 ton ds/ha. De zetmeelgehalten van het C7-lijn (met 2 plantdichtheden) en de hybriderassen HDD-1, HDD-2, HDD-3 zijn gemiddeld $410 \mathrm{~g} / \mathrm{kg}$ ds - dit is $24 \%$ hoger dan bij snijmaïs - wat als zeer goed kan worden gekenmerkt. Opvallend is dat de C7-lijn nu al competitief is met snijmaïs. C7 levert $10 \%$ meer eiwit en $20 \%$ meer zetmeel per ha op dan snijmaïs. De hybride HDD-2 levert zelfs $60 \%$ meer zetmeel per ha dan snijmaïs (opbrengst: 8,3 vs 5,2 ton zetmeel/ha). De hybride Vegga was duidelijk nog niet voldoende afgerijpt, af te leiden uit het nog hoge suikergehalte. De VCOS-percentages van alle sorghumrassen liggen lager dan van snijmaïs. De drogestofpercentages liggen op een goed gehalte (30-35\%), behalve voor Vegga 2.0, die nog onvoldoende was afgerijpt. Een hogere plantdichtheid - te zien bij de lijn C7 2.75 en hybride Vegga 2.75 - geeft geen hogere opbrengst. Het ruw-eiwitgehalte van de sorghumrassen (behalve Vegga 2.75 ) is $8-13 \%$ hoger dan die van snijmaïs. 
In 2016 heeft kweker De Milliano (Zeeuws-Vlaanderen) 22 lijnen geplant bij vier verschillende zaaidata - 7 mei, 14 mei, 30 mei en 14 juni - op proefvelden van elk 1,8 $\mathrm{m}^{2}$. Van deze 88 veldjes is per veld $50 \%$ van de biomassa geoogst, vervolgens gehakseld en zijn monsters genomen van ca. 0,5 tot 1,0 kg per stuk. Het vers gewicht van de monsters werd bepaald, waarna ze werden ingevroren. Vanaf april 2017 zijn alle monsters gedroogd $\left(70^{\circ} \mathrm{C}\right)$, waardoor het luchtdrogestofgehalte werd vastgesteld. Uit het vers gewicht en het drogestofgehalte zijn de drogestofhoeveelheden per veld bepaald en daarmee kon van elke lijn per zaaidatum de opbrengst in ton ds/ha worden bepaald (tabel 7). De drogestofgehalten van de 88 monsters zijn weergegeven in bijlage 1 . Door de bepaling van het luchtdrogestofgehalte kan de drogestofhoeveelheid maximaal $2 \%$ overschat zijn; voor graansorghum zal de overschatting maximaal $3 \%$ zijn.

Tabel 7 Opbrengsten van 22 lijnen sorghum bij vier zaaidata (ton droge stof/ha); de drogestofgehalten van de verse opbrengsten staan vermeld in bijlage 1.

\begin{tabular}{|c|c|c|c|c|c|c|}
\hline \multirow[t]{2}{*}{ Lijn/ ras } & \multirow[t]{2}{*}{ Naam ras } & \multirow[t]{2}{*}{ No Zaad, g } & \multicolumn{4}{|c|}{ Zaaidatum } \\
\hline & & & $7-5-2016$ & $14-5-2016$ & $30-5-2016$ & $14-6-2016$ \\
\hline & & & $171 \mathrm{dnz} *$ & $164 \mathrm{dnz}$ & $151 \mathrm{dnz}$ & $136 \mathrm{dnz}$ \\
\hline 1 & Sorghum nigricans & 2.5 & 14.3 & 17.9 & 15.5 & 18.9 \\
\hline 2 & Sorghum nigricans & 5 & 13.8 & 11.8 & 14.3 & 21.7 \\
\hline 3 & Sorghum nigricans & 7.5 & 13.8 & 14.7 & 17.1 & 15.5 \\
\hline 4 & Sorghum nigricans & 10 & 10.6 & 17.4 & 19.4 & 19.2 \\
\hline \multirow[t]{3}{*}{5} & Sorghum nigricans & 5 & 15.0 & 12.6 & 18.8 & 16.6 \\
\hline & S. nigricans, Gemidd. & & 13.5 & 14.9 & 17.0 & 18.4 \\
\hline & CV** & & 0.13 & 0.18 & 0.13 & 0.13 \\
\hline 6 & Sorghum bicolor & 5 & 28.1 & 32.2 & 33.2 & 20.2 \\
\hline 7 & Sorghum bicolor & 2.5 & 24.3 & 21.7 & 9.1 & 10.6 \\
\hline 8 & Sorghum bicolor & 5 & 42.5 & 33.2 & 31.7 & 19.7 \\
\hline 9 & Sorghum bicolor & 7.5 & 26.6 & 29.5 & 22.8 & 19.3 \\
\hline 10 & Sorghum bicolor & 10 & 17.7 & 30.3 & 24.8 & 12.5 \\
\hline 11 & Sorghum bicolor & 5 & 22.5 & 26.1 & 29.4 & 26.3 \\
\hline 12 & Sorghum bicolor & 5 & 18.9 & 23.8 & 17.0 & 20.9 \\
\hline 13 & Sorghum bicolor & 5 & 12.8 & 19.3 & 17.5 & 20.6 \\
\hline 14 & Sorghum bicolor & 5 & 22.0 & 17.5 & 17.5 & 22.1 \\
\hline 15 & Sorghum bicolor & 5 & 13.0 & 17.1 & 11.9 & 6.0 \\
\hline \multirow[t]{3}{*}{16} & Sorghum bicolor & 5 & 12.9 & 16.9 & 9.3 & 3.6 \\
\hline & S. bicolor, Gemidd. & & 21.9 & 24.3 & 20.4 & 16.5 \\
\hline & CV & & 0.40 & 0.26 & 0.42 & 0.44 \\
\hline 17 & Sorghum soedangras & 5 & 5.3 & 15.5 & 15.1 & 23.4 \\
\hline \multirow[t]{3}{*}{18} & Sorghum soedangras & 5 & 8.9 & 13.4 & 8.8 & 13.6 \\
\hline & S. soedangras, Gem. & & 7.1 & 14.5 & 12.0 & 18.5 \\
\hline & CV & & 0.36 & 0.10 & 0.37 & 0.37 \\
\hline 19 & S. bicolor $\times$ S. bicolor & 2.5 & 11.6 & 21.1 & 16.6 & 8.4 \\
\hline \multirow[t]{3}{*}{20} & S. bicolor x S. nigric. & 2.5 & 26.1 & 24.2 & 24.5 & 21.4 \\
\hline & S. Bicolor x S. Gem. & & 18.9 & 22.7 & 20.6 & 14.9 \\
\hline & CV & & 0.54 & 0.10 & 0.27 & 0.62 \\
\hline 21 & Pennisetum glaucum & 5 & 13.3 & 6.2 & 8.1 & 2.3 \\
\hline \multirow[t]{3}{*}{22} & Pennisetum glaucum & 5 & 8.3 & 13.4 & 18.3 & - \\
\hline & P. glaucum, Gemidd. & & 10.8 & 9.8 & 13.2 & - \\
\hline & CV & & 0.33 & 0.52 & 0.55 & \\
\hline
\end{tabular}

* dnz $=\ldots$ dagen na zaaien geoogst

** $\quad \mathrm{CV}=$ variatiecoëfficiënt 
Tabel 7 laat duidelijke opbrengstverschillen zien tussen de sorghumsoorten, rassen en tussen sorghum en parelgierst (Pennisetum glaucum). S. bicolor geeft de hoogste opbrengsten bij zaaien op 7 mei en 14 mei. Bij zaaien in mei waren er gemiddelde opbrengsten van meer dan 20 ton ds/ha op, waarbij de zaaidatum van 14 mei de hoogste gemiddelde opbrengst geeft: bijna 25 ton ds/ha. In juni zaaien is minder geschikt voor de rassen 15 en 16, omdat de opbrengsten dan gemiddeld nog geen 8 ton ds/ha leveren. S. nigricans geeft bij de twee eerste zaaidata sterk lagere opbrengsten dan S. bicolor, maar de opbrengsten worden bij een later zaaitijdstip steeds hoger. Gezien de relatief lagere opbrengsten is de eerste zaaidatum voor de twee lijnen van S. soedangras te vroeg. De hybride S. bicolor $\mathrm{x}$ S. nigricans geeft hoge en constante opbrengsten. De beide $P$. glaucum reageren wat betreft piekopbrengsten verschillend op het tijdstip van zaaien. De variatiecoëfficiënten (CV) van S. bicolor en S. soedangras zijn nogal groter dan van S. nigricans.

De drogestofpercentages van de variëteiten S. nigricans zijn hoog en met lage variatiecoëfficiënten (bijlage 1). Dit gewas biedt bij laat zaaien - juni en wellicht juli - goede mogelijkheden voor toepassing als veevoeder, te meer daar bekend is dat bij het optimale oogsttijdstip het percentage ruw-eiwit in het blad hoger dan $20 \%$ is, afhankelijk van de oogstdatum; begin oktober hoger dan eind oktober (De Milliano, 2017). Er moet dan een afweging gemaakt worden tussen groen blad met veel eiwit en een lager percentage zaad vanuit de pluim of meer verwelkt blad met meer lignine (met ruweiwitpercentages lager dan 10\%) en meer zaadvorming. Meer zaadvorming geeft een hoger zetmeelgehalte. Het gewas gaat bij zetmeelgehalten van ca. $350-400$ g/ kg ds meer lijken op maïs. Hierbij is het de vraag welke drogestofopbrengst kan worden gehaald.

Bij de opbrengsten van tabel 7 zijn enkele kanttekeningen te plaatsen. De genoemde lijnen werden geteeld op relatief kleine proefvelden $\left(1,8 \mathrm{~m}^{2}\right)$, waarvan $50 \%$ is geoogst. Door het natte voorjaar van 2016 waren de proefomstandigheden niet ideaal en was er variatie in opkomst en groeiomstandigheden binnen het proefveld. De oogstdatum - eind oktober - is echter weer tamelijk laat voor het verkrijgen van een optimale kwaliteit, maar is gekozen om het effect van laat oogsten te testen. Vertaling naar de praktijksituatie is niet rechtstreeks mogelijk, omdat lokale bodem- en weersomstandigheden de opbrengst positief of negatief kunnen beïnvloeden. Bovendien zijn er geen herhalingen toegepast in deze proefopzet.

\subsubsection{C-vastlegging in bodem}

De jaarlijkse bijdrage van organische plantaardig materiaal in de bodem is een belangrijke component in de opbouw van organische stof in de bodem. Daarin is het kwantificeren van de organische C-input, afgeleid van plantenwortels in de bodem, nodig om een uitspraak te kunnen doen over de Cvastlegging in de bodem. Wortels spelen en belangrijke rol in $\mathrm{C}$ - en $\mathrm{N}$-cycli en hebben waarschijnlijk een relatief grotere invloed op bodem- $\mathrm{C}$ en bodem- $\mathrm{N}$ dan de bovengrondse biomassa (Boone, 1994). De hoeveelheden $\mathrm{C}$ afkomstig van wortels of wortelmassa variëren afhankelijk van milieucondities, managementsystemen, ras, en de fysische, chemische en biologische eigenschappen van de bodem (Balesdent et al., 1992). Wortelontwikkeling is erg gevoelig voor variaties in het toedienen en de verdeling van anorganische nutriënten en water (Steingrobe et al., 2001), waardoor de wortelmassa aanzienlijk kan variëren. Echter, afscheidingsproducten van de wortel, zoals slijm en andere afscheidingsproducten, dode cellen van groeiende wortels, en afgesleten wortelpunten dragen aanzienlijk bij aan de groei van de 'Soil Organic Carbon' (SOC; Crawford et al., 1996). Deze bijdrage vergroot de microbiële activiteit en beïnvloedt de $\mathrm{N}$-mineralisatie in de bodem (Bakken, 1990), maar is echter moeilijk te meten met conventionele methoden.

\section{Vergelijking maïs en sorghum}

De bijdrage van deze afscheidingsproducten van de wortel aan SOC in het groeiseizoen is bij planten in het algemeen meer dan $580 \mathrm{~kg} \mathrm{C} /$ ha (Helal et al., 1987). Fernandez et al. (2003) geven aan dat van genoemde biomassa bij Sorghum bicolor $1.000 \mathrm{~kg} \mathrm{C} /$ ha aan SOC bijdraagt. Wat betreft wortelmassa per groeiseizoen levert maïs met daarna een vanggewas $0,4-1,4$ ton $\mathrm{C} /$ ha ofwel 1,5 5,1 ton $\mathrm{CO}_{2}$ /ha (Kuo et al.,1997), maar voor Sorghum bicolor is deze bijdrage veel groter: 5,2 ton $\mathrm{C}$ /ha ofwel 19,1 ton $\mathrm{CO}_{2}$ /ha per groeiseizoen (Fernandez et al., 2003). De bevindingen suggereren dat de opname van sorghum in gewasrotaties, de koolstofvastlegging in het gehele bodemprofiel aanzienlijk kan verhogen - 4 tot 13 maal hoger dan in (snij)maïs -, wat eveneens gunstig is voor het totale bodemprofiel. 
Naast het verschil in de hoogte van de koolstofbijdrage (of $\mathrm{CO}_{2}$-bijdrage) levert sorghum deze bijdrage ook sneller dan snijmaïs. Wanneer sorghum geteeld wordt na een $\mathrm{C} 3$-gewas neemt de $\mathrm{CO}_{2}$-bijdrage in drie jaar toe tot $28 \%$ in de toplaag $(0-30 \mathrm{~cm})$. In diepere lagen - van 30 tot $210 \mathrm{~cm}$ - is het aandeel van sorghum lager, maar neemt duidelijk toe vanaf het eerste jaar na wisseling (Celano et al., 2012). Echter, bij een langdurige opbouw van SOC bij maïsteelt, was het aandeel van maïskoolstof (SOC) in de totale bodem-SOC laag: 25-35\% voor een periode van 25 jaar continuteelt maïs in een kleileemlaag bodem in Canada (Gregorich et al., 1995), 15\% na 27 jaar continuteelt maïs in Duitsland op een lemige zandgrond (Flessa et al., 2000), en 44\% op een zilte lemige maïsgrond in Frankrijk voor een periode van 23 jaar maïsteelt (Puget et al., 1995).

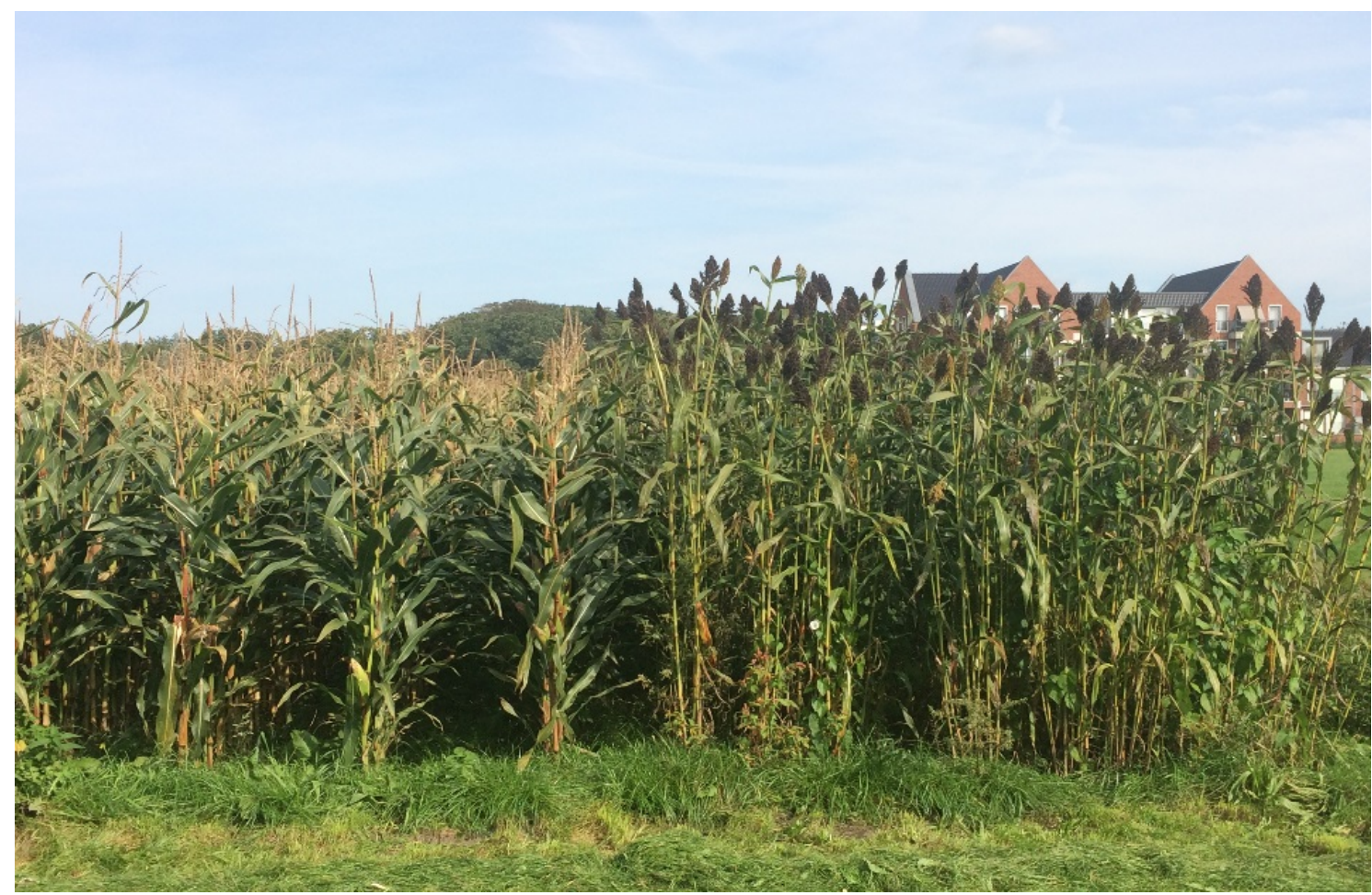

Figuur 3 Maïsteelt (links) en teelt van CN1-sorghum (rechts) te Joure, Nederland, 21 sept. 2017 (bron: De Milliano). 


\section{$4 \quad$ Introductie sorghum in Nederland?}

\section{Sorghum als tussenteelt van snijmaïs}

Vers gras, graskuil en snijmaïskuil zijn de belangrijkste ruwvoeders voor de Nederlandse melkveehouderij. De vleesstieren- en rosékalverhouderij leggen beslag op ruim 9.000 ha van het totale snijmaïsareaal in Nederland van ca. 205.000 ha in 2017 (Van Schooten, 2017). Hoewel in Nederland al 50 jaar snijmaïs geteeld wordt, vindt nog veel monocultuur van maïs plaats. Nadeel hiervan is dat deze continuteelt op termijn leidt tot opbrengstderving door verlies van organische stof, opbouw van bodemgebonden ziekten en verdichting. Sorghum kan als derde voedergewas op een melkveebedrijf hierin verandering brengen. Dit gewas wortelt dieper, waardoor het efficiënter met stikstof en water ( $25 \%$ minder water nodig dan maïs) omgaat. Het gewas kan tijdens droogte de bloei- en korrelzetting uitstellen.

Zoals vermeld in paragraaf 2.3 is sorghum minder gevoelig voor schimmels en resistent tegen de quarantaineplaag van de maïswortelboorder. Hierdoor kan sorghum een sanerend effect hebben op bodemgebonden ziekten en geeft als tussenteelt een rotatieveruiming waar maïs van profiteert tot uiting komend in een potentieel hogere opbrengst van 6-9\% (Van de Goor et al., 2017). De lagere gevoeligheid van sorghum voor schimmels en de door deze schimmels geproduceerde mycotoxinen geeft sorghum een voorkeurspositie t.o.v. snijmaïs. Studies van Van der Fels-Klerx et al. (2016) en Battilani et al. (2016) geven scenario's aan over toename in aantasting van (snij) maïs door een aantal schimmels met bijbehorende mycotoxinen als gevolg van de te verwachten klimaatverandering in Europa. Als voorbeeld wordt Noord-Italië genoemd waar door hittegolven in 2003 en 2009 een ernstige besmetting met aflatoxine M1 in maïs - die in de regio geteeld werd - optrad, veroorzaakt door de aanwezigheid van de schimmel Aspergillus Flavus die voor de $21^{\mathrm{e}}$ eeuw alleen maar in (sub)tropische gebieden te vinden was. Aflatoxine M1 is gevormd uit aflatoxine B1 door omzetting in de lever van de melkkoe en bleek in de melk (vandaar letter M) aanwezig te zijn (Giorni et al., 2007). Aflatoxine M1 is even giftig, maar minder kankerverwekkend dan aflatoxine B1. Bij inname van te grote hoeveelheden aflatoxine kunnen levertumoren ontstaan. Hoewel sorghumrassen beter resistent zijn tegen schimmelaantasting, is het de vraag in welke mate aantasting zal optreden tijdens droge en hete zomers bij de nu ontwikkelde sorghum-hybriden in Nederland. Dat zal een aspect van toekomstig onderzoek moeten zijn.

De nogal hogere C-vastlegging van sorghum in de bodem geeft een betere microbiële activiteit en $\mathrm{N}$ mineralisatie en geeft een hoger vasthoudend vermogen voor water. Snijmaïs als volgteelt kan hiervan profiteren met een hogere opbrengst en een lagere kans op bodem- en watererosie (Vogel et al., 2016; Nantier, 2015).

\section{Sorghum als tweede gewas in groeiseizoen}

Bepaalde selecties van Sorghum nigricans zijn beter geschikt om later in het groeiseizoen te zaaien (de eerste helft van juni), omdat ze dan hogere drogestofopbrengsten geven en ook nog goed afrijpen (paragraaf 3.1.3, tabel 6, bijlage 1, De Milliano, 2017). Deze variëteit is erg geschikt voor veevoer door het hoge eiwitgehalte ( $>20 \%$ in ds) bij vroeg oogsten (begin oktober), waarbij wel een lagere VEM (netto energiewaarde voor melkvee) gerealiseerd wordt. Laat oogsten (eind oktober) geeft een normaal eiwitgehalte (9-11\% in ds) gecombineerd met een hoger zetmeelgehalte, zoals vermeld in paragraaf 3.1.3. Sorghum nigricans kan goed geteeld worden na de teelt van winterrogge bestemd als veevoer. De rogge moet bij voorkeur vroeg in de herfst gezaaid worden (begin oktober) om een goede beginontwikkeling te hebben in het voorjaar (Van den Pol et al., 2000; Wagenaar et al., 2003). Deze winterrogge kan eind juni/begin juli geoogst worden in het deegrijpe stadium. De gemiddelde opbrengst bedraagt 8,5 ton ds/ha. Daarna kan Sorghum nigricans gezaaid worden en zal dan nog opbrengsten geven - afhankelijk van het oogsttijdstip - van 10-14 ton ds/ha met hoge eiwitgehalten (ca. $200 \mathrm{~g} / \mathrm{kg} \mathrm{ds}$ ) of 18 ton ds/ha met lage eiwitgehalten (ca. $100 \mathrm{~g} / \mathrm{kg} \mathrm{ds}$ ). Het is van groot belang dat de oogstdata van beide gewassen goed gekozen worden om de voederwaardes en drogestofgehaltes, inkuilbaarheid en verteerbaarheid bij het inkuilen zo optimaal mogelijk te laten zijn. Een te laag drogestofgehalte $(<30 \% \mathrm{ds}$ ) geeft een grotere kans op vochtverliezen in de kuil, maar 
een te hoog drogestofgehalte ( $>45 \%$ ds) verhoogt de kans op een minder goede inkuilbaarheid door luchtintreding. Ook speelt de oogsttechniek een rol bij zowel de deeltjesgrootte van het gehakselde materiaal als de kneusgraad van maïskorrels. Een kleinere deeltjesgrootte vermindert luchtintreding en geeft daardoor beter verdichte kuilen. De kneusgraad beïnvloedt de verteerbaarheid van het geconserveerde voer in de melkkoe.

\section{Voederwaardebepaling}

Sorghum wordt op geringe schaal geteeld in Noordwest-Europa. Dit heeft consequenties voor de voederwaardering. Van geoogste sorghum afkomstig van proefpercelen is de VEM-waarde bepaald, maar ook zijn er in vitro Tilly\&Terry $(=T \& T)$ testen uitgevoerd en daaruit blijkt dat de verteringscoëfficiënten van de organische stof, bepaald via de T\&T test, hoger liggen dan de VCOS voorspeld via de NIRS-analyse van Eurofins (voorheen BLGG). Het lijkt dat de gebruikte ijklijnen niet geschikt zijn voor sorghum. Om tot een betrouwbare VEM-waardering van sorghumsilage te komen is het nodig om met monsters van sorghumsilage de in vivo fecale verteerbaarheden van RE, RVET, RC, OK, organische stof en zetmeel in hamels te bepalen. Om een betrouwbaar beeld te krijgen van de eiwitwaarde van sorghum zijn pensfermentatie-karakteristieken nodig en data over de darmverteerbaarheid. Deze zijn momenteel niet of nauwelijks beschikbaar. 


\section{Conclusies en aanbevelingen}

\section{$5.1 \quad$ Conclusies}

- Ongeveer $75 \%$ (d.w.z. 44 miljoen ton (= $44 \mathrm{M}$ ton)) van het sorghumgraan op wereldschaal wordt in een beperkt aantal landen geproduceerd: $20 \mathrm{M}$ ton in de VS en Zuid Amerika, $10 \mathrm{M}$ ton in Zuidoost-Azië, $13 \mathrm{M}$ ton in Afrika en $1 \mathrm{M}$ ton in Australië. De Europese productie aan sorghumgraan is $0,3 \mathrm{M}$ ton.

- $\quad$ Sorghum als voedergewas is vooral te vinden in Mexico, Argentinië en de VS. Het aandeel is $80 \%$ van de totale wereldproductie. In Europa is de productie als voedergewas gering en vindt vooral plaats in Frankrijk, I talië en Hongarije.

- In Europa is sorghum als voedergewas onderzocht in vooral Noord-I talië (Po-vlakte) op eigenschappen van inkuilbaarheid, voeropname, melkproductie, melksamenstelling en broeikasgasemissies. Hierbij zijn vergelijkingen met snijmaïs beschreven. De resultaten gaven aan dat de voeropname van snijmaïs en graansorghum gelijk zijn, maar die van foragesorghum lager is dan van snijmaïs en graansorghum. De melkproductie van het melkvee op een rantsoen met forage-sorghum is lager dan van een rantsoen met één van de beide andere gewassen. Verder bleek dat de broeikasgasemissies voor de LCA-keten "cradle to farm-gate" van maïs lager zijn dan van die van forage-sorghum door het hogere krachtvoerverbruik. Deze hogere emissie geldt ook gedeeltelijk voor graansorghum, maar werd grotendeels teniet gedaan door de lagere emissies dan maïs tijdens de teeltperiode.

- Sorghum kan geteeld worden op de meeste bodemtypen, kan goed tegen droge, maar minder tegen natte omstandigheden, vraagt $75 \%$ van de vochtbehoefte van snijmaïs, heeft minder stikstof nodig en gaat efficiënt met stikstof om. Onder Nederlandse omstandigheden komen schimmelziekten tot op heden nog minder frequent voor, en zijn volgens de literatuur minder ernstig in sorghum- dan in snijmaïskuil. Ook is sorghum geen gastheer voor de maïswortelboorder.

- De gemiddelde drogestofopbrengst van sorghum als voedergewas is in Frankrijk lager dan van geïrrigeerde snijmaïs. De melkgift verschilde niet bij silage van graansorghum, maar was lager bij silage van sweet sorghum. Uit Italiaans onderzoek blijkt dat sorghum een lagere opbrengst heeft en een lagere voederwaarde dan snijmaïs. Dit resulteert in een lagere (forage-sorghum) tot gelijke melkproductie (graansorghum) van melkvee.

- In Nederland zijn door een kweker (De Milliano) eigen lijnen van sorghum als voedergewas ontwikkeld. Proefveldopbrengsten (oogst eind oktober 2016) op locatie Oostburg lieten zien dat bij vier zaaidata de hoogste opbrengsten geleverd werden bij zaaien $1^{\mathrm{e}}$ helft mei (Sorghum bicolor) en bij zaaien $1^{\mathrm{e}}$ helft juni (Sorghum nigricans).

- Recente proeven toonden opbrengsten van sorghum die varieerden van 15 tot 20 ton ds/ha. De zetmeelgehalten van de C7-lijn (met 2 zaaidichtheden) en drie hybride-sorghumrassen (HDD) waren gemiddeld $410 \mathrm{~kg}$ ds/ha, dit is $24 \%$ hoger dan van snijmaïs. De in Nederland ontwikkelde sorghumlijn (C7) toonde een competitieve opbrengst met hybriden van sorghum veredeld in het buitenland (Vegga) en met snijmaïs; de C7-lijn gaf 10\% meer eiwit en 20\% meer zetmeel per ha dan snijmaïs. De VCOS-percentages van alle sorghumrassen liggen lager dan snijmaïs (2-5\%) De drogestofpercentages liggen op een goed niveau (30-35\%), behalve voor de sorghumhybride Vegga die nog onvoldoende was afgerijpt. Een hogere plantdichtheid geeft geen hogere opbrengst. Het ruw-eiwitgehalte van de sorghumrassen is, afhankelijk van het ras, tot $13 \%$ hoger dan van snijmaïs.

- Mogelijke toepassingen van sorghum in Nederland op korte termijn zijn: 1) éénmalige teelt sorghum, 2) tussenteelt om de nadelige aspecten van maïs als monocultuur te doorbreken, en 3) tweede gewas in groeiseizoen na b.v. een teelt van winterrogge als voedergewas.

- Het genetisch potentieel van sorghum is groot. Onderzoek naar opkomst, opbrengst en voederwaarde en broeikasgasemissies is gewenst. 
- De teeltkosten van sorghum uit Frans onderzoek zijn lager dan die van snijmaïs veroorzaakt door lagere kosten voor zaaizaad, kunstmest, pesticiden en geen gebruik van beregening.

- Op dit moment is de voederwaardebepaling van sorghum niet goed vast te stellen, vanwege niet-geschikte ijklijnen voor sorghum.

- De bijdrage van Sorghum bicolor aan SOC in de bodem is wat betreft uitscheidingsproducten van de wortels met 1 ton $\mathrm{C} / \mathrm{ha}$ /groeiseizoen bijna tweemaal zo hoog als van de gemiddelde plant. De bijdrage van de wortelmassa aan SOC is van Sorghum bicolor zelfs aanzienlijk hoger dan van snijmaïs respectievelijk 5,2 versus $0,4-1,4$ ton $C /$ ha/groeiseizoen. Dit betreft niet alleen de toplaag $(30 \mathrm{~cm}$ ), maar na enkele opeenvolgende jaren sorghumteelt geldt dit ook voor het bodemprofiel van 30 tot $210 \mathrm{~cm}$ onder het maaiveld.

\subsection{Aanbevelingen}

Deze studie heeft een aantal vragen en discussiepunten opgeroepen, die door nader onderzoek ingevuld kunnen worden. De belangrijkste kennishiaten voor onderzoek in Nederland zijn:

- Voederwaardering sorghum: het ontbreekt voornamelijk aan gegevens over de (darm) verteerbaarheid en de afbreekbaarheid in de pens.

- Recent onderzoek naar opbrengst en voederwaarde van sorghum op praktijkvelden geeft perspectief voor de toekomst. Echter, doorgaand veredelingsonderzoek is gewenst, vooral naar de beginontwikkeling, lange daglengte van sorghum en naar vroegrijpe rassen. De (melk) veehouderij vraagt naar concrete cijfers van opbrengst en voederwaarde onder praktijkomstandigheden.

- Naast teeltonderzoek hebben veehouders ook inzicht nodig in de conserveringseigenschappen van sorghum evenals kennis over opname van ingekuilde sorghum en melkgiften door melkvee. Kennis hierover is van belang om een vergelijking te hebben met (snij)maïs.

- Onderzoek naar broeikasgasemissies voor de keten "cradle to farm-gate" en C-vastlegging in de bodem van een sorghumsoort die wat betreft voederaspecten goed scoort is gewenst om de duurzaamheid van sorghum als voedergewas te kunnen bepalen.

- Vergelijkend onderzoek naar teeltkosten van sorghum en snijmaïs is gewenst.

- $\quad E r$ is een aantal voordelen van de teelt van sorghum bekend in vergelijking met snijmaïs, o.a. op de gebieden droogtegevoeligheid / veel neerslag, stikstofbenutting, vorming van organische stofgehalte in bodem, bodemverdichtingen, en vatbaarheid voor plagen / ziekten en minder kans op erosie. Deze voordelen zouden getoetst moeten worden in de praktijk bij éénmalige teelt van sorghum, bij teelt van twee gewassen (bijv. winterrogge en sorghum) en als tussenteelt ter onderbreking van continuteelt van (snij)maïs. 


\section{$6 \quad$ Literatuur}

Abdelhadi, L.O. \& J.M. Tricarico, 2009. Effects of stage of maturity and microbial inoculation at harvest on nutritive quality and degradability of grain sorghum whole-plant and head-chop silages. Animal Feed Science and Technology 152: 175-185.

Almodares, A., M.R. Hadi, \& B. Dosti, 2008. The effects of salt stress on growth parameters and carbohydrate contents in sweet sorghum. Research Journal of Environmental Science 2, 298-304.

Ashbell, G. \& Z.G. Weinberg, 2000. Silage from tropical cereals and forage crops. Forage preservation and by-products Research Unit, Agricultural Research Organization (ARO). The Volcani Center, Bet Dagan 50250 Israel, 8 pp.

Bakken, L.R., 1990. Microbial growth and immobilization / mineralization of $\mathrm{N}$ in the rhizosphere. Symbiosis 9: 37-41.

Balesdent, J. \& M. Balabane, 1992. Maize root-derived soil organic carbon estimated by natural ${ }^{13} \mathrm{C}$ abundance. Soil Biol. Biochem. 24: 97-101.

Battilani, P., P. Toscano, H.J. Van der Fels-Klerx, A. Moretti, M. Camardo Leggieri, C. Brera, A. Rortais, T. Goumperis \& T. Robinson, 2016. Aflatoxin B1 contamination in maize in Europe increases due to climate change. Sci. Rep. 6, 24328; doi: 10.1038/srep24328.

Berenji, J. \& J. Dahlberg, 2004. Perspectives of sorghum in Europe. J ournal of Agronomy and Crop Science 190, 332-338.

Bernard, J.K. \& S. Tao. 2015. Short communication: Production response of lactating dairy cows to brachytic forage sorghum silage compared with corn silage from first or second harvest. J. Dairy Sci. 98: 8994-9000.

Bhat, R., P.H. Shetty, R.P. Amruth \& R.V. Sudershan, 1997. A foodborne disease outbreak due to the consumption of moldy sorghum and maize containing fumonisin mycotoxins, Journal of Toxicology: Clinical Toxicology, 35:3, 249-255.

Boone, R.D., 1994. Light-fraction soil organic matter: origin and contribution to net nitrogen mineralization. Soil Biol. Biochem. 26: 1459-1468.

Cattani, M., N. Guzzo, R. Mantovani \& L. Bailoni, 2017. Effects of total replacement of corn silage with sorghum silage on milk yield, composition, and quality. Journal of Animal Science and Biotechnology 8: 15 .

Celano, G., F. Alluvione, M.A.A.A. Mohamed \& R. Spaccini, 2012. The stable isotopes approach to study $\mathrm{C}$ and $\mathrm{N}$ sequestration processes in a plant-soil system. In: Piccolo A. (ed.) Carbon Sequestration in Agricultural Soils: A Multidisciplinary Approach to innovative systems. DOI 10.1007/978-3-642-23385-2. Springer Heidelberg Dordrecht London New York.

Chilaka, C.A., M. De Boevre, O.O. Atanda \& S. De Saeger, 2016. Occurence of Fusarium mycotoxins in cereal crops and processed products (Ogi) from Nigeria. Toxins 2016, 8, 342; doi: $10.3390 /$ toxins8110342.

Colombini, S., M. Zucali, L. Rapetti, G. M. Crovetto, A. Sandrucci \& L. Bava, 2015. Substitution of corn silage with sorghum silages in lactating cow diets: In vivo methane emission and global warming potential of milk production. Agricultural Systems 136: 106-113.

Crawford, M.C., P.R. Grace, W.D. Bellotti \& J.M. Oades, 1996. Belowground inputs of carbon by crops and pastures. In: Proceedings of the eighth Australian Agrono conference, Toowoomba, Australia. http://www.regional.org.au/au/asa/1996/contributed/index.htm

De Milliano, W.A.J., 2017. Persoonlijke mededeling.

De Milliano, W.A.J., R.A. Frederiksen \& G.D. Bengston, 1992. Sorghum and millets diseases: a second world review. International Crops Research Institute for the Semi Arid Tropics, 378 pp.

De Wit, J. \& N. van Eekeren, 2016. Sorghum: derde gewas met potentie. V-focus, juni 2016: 33-34.

Dvořáčková, J., P. Doležal \& I. Vyskočil, 2013. Effect of the growing season duration of sorghum and Sudan grass hybrids on the chemical composition and digestibility of organic matter. Acta Universitatis Agriculturae et Silviculturae Mendelianae Brunensis, 61 (6): 1629-1635.

Emile, J.C., M. Al Rifaï, X. Charrier, P. Leroy \& Y. Barriere, 2006. Grain sorghum silages as an alternative to irrigated maize silage. Grassland Science 80 in Europe, 11: 80-82. 
European Commission, 1991. Directive of the Council of December 12 concerning the protection of waters against pollution caused by nitrates from agricultural sources (91/676/EEC). European Commission, Brussels, Belgium.

Fenandez, J., M.D. Curt, P. Aguado \& E. Magro, 2003. Carbon allocation in a sweet sorghum-soil system using ${ }^{14} \mathrm{C}$ as tracer. J. Plant Nutr. Soil Sci. 166:23-30.

Flessa, H., B. Ludwig, B. Heil \& W. Merbach, 2000. The origin of soil organic C, dissolved organic C and respiration in a long-term maize experiment in Halle, Germany, determined by ${ }^{13} \mathrm{C}$ natural abundance. J. Plant Nutr. Soil Sci. 163: 157-163.

Gardner, J.C., J W. Maranville \& E.T. Paparozzi. 1994. Nitrogen use efficiency among diverse sorghum cultivars. Crop Sci. 34: 728-733.

Giorni, P., N. Magan, A. Pietri, T. Bertuzzi \& P. Battilani, 2007. Studies on Aspergillus section Flavi isolated from maize in northern Italy. International J ournal of Food Microbiology 113: 330-338.

Gregorich, E.G., B.H. Ellert \& C.M. Monreal, 1995. Turnover of soil organic matter and storage of corn residue carbon estimated from natural ${ }^{13} \mathrm{C}$ abundance. Can. J. Soil Sci. 75: 161- 167.

Helal, H.M. \& D. Sauerbeck, 1987. Direct and indirect influences of plant root on organic matter and phosphorus turnover in soil. In: Couley J.H. (ed.) Soil organic matter dynamics and soil productivity. Intecol. Bull. 15 Int. Assoc. for Ecol., Athens, GA, pp 49-58.

Hermuth, J., D. Janovská, P. Hlásná Čepková, S. Ustáak, Z. Strašil \& Z. Dvořáková, 2016. Sorghum and Foxtail Millet-Promising Crops for the Changing Climate in Central Europe. Alternative Crops and Cropping Systems (Book, chapter1), 27 p. Doi: 10.5772/62642.

Kálmán, L. \& E. Rajki, 2016. Silage sorghum and maize intercropping in Hungary. Cereal Research Non-Profit Ltd. 6726 Szeged Alsókikötő sor 9. Hungary.

Kovács, G.P., 2014. Development of sweet sorghum cultivation techniques for alternative energy purposes. Thesis of doctoral dissertation, Gödöllö, 28 pp.

Kuo, S., U.M. Sainju \& E.J. Jellum, 1997. Winter cover crop effects on soil organic carbon and carbohydrate. Soil Sci. Soc. Am. J. 61:145-152.

Leslie, J.F., 2002. Sorghum and millets diseases. I owa State Press, 504 pp.

Mahmood, A., 2012. Performance of Sorghum (Sorghum bicolor L. Moench) as an Energy Crop for Biogas Production. Thesis of doctoral degree in agriculture. $139 \mathrm{pp}$.

Nantier, G., 2015. Erosie bedreigt maïsteelt. Veeteelt, februari 2015, p. 48-49.

Osuna-Ortega, J., M. del C. Mendoza-Castillo \& L.E. Mendoza-Onofre, 2003. Sorghum cold tolerance, pollen production and seed yield in the Central High Valleys of Mexico. Maydica 48, 125-132.

Oyediran, I.O., B.E. Hibbard \& T.L. Clark, 2004. Prairie grasses as hosts of western corn root worm (Coleoptera: Chrysomelidae). Environmental Entomology 33 (3): 740-747.

Premachandra, G.S., D.T. Hahn, J.D. Axtell \& R.J. Joly, 1994. Epicuticular wax load and water use efficiency in bloomless and sparse-bloom mutants of Sorghum bicolor L. Moench. Environmental and Experimental Botany 34: 293-301.

Puget, P., C. Chenu \& J. Balesdent, 1995. Total and young organic matter distributions in aggregates of silty cultivated soils. Eur. J. Soil Sci. 46:449-459.

Reddy, B.V.S., A.A. Kumar, S. Ramesh \& P.S. Reedy, 2011. Sorghum genetic enhancement for climate change adaptation. In: Yadav, S.S., R. Redden, J.L. Hatfield, H. Lotze-Campen, A.J.W. Hall (eds.) Crop adaptation to climate change, 1st edn. Oxford (UK), Wiley-Blackwell.

Rehm, S. \& G. Espig, 1996. Die Kulturpflanzen der Tropen und Subtropen. Stuttgart, Eugen Ulmer.

Robertson, M.J., S. Fukai, M.M. Ludlow \& G.L. Hammer, 1993. Water extraction by grain sorghum in a sub-humid environment. II. Extraction in relation to root growth. Field Crops Research 33: 99112.

Singh V., E.J . van Oosterom, D.R. Jordan, C.D. Messina, M. Cooper \& G. L. Hammer, 2010. Morphological and architectural development of root systems in sorghum and maize. Plant and Soil 333, 287-299.

Singh, V., C.T. Nguyen, E.J. van Oosterom, S.C. Chapman, D.R. J ordan \& G.L. Hammer, 2015. Sorghum genotypes differ in high temperature responses for seed set. Field Crops Research 171: 32-40.

Sleper, D.A. \& J.M. Poehlman, 2006. Breeding Field Crops. 5th ed. Ames (IA), Blackwell Publishing Professional.

Steingrobe, B., H. Schmid \& N. Claassen, 2001. Root production and root mortality of winter barley and its implication with regard to phosphate acquisition. Plant Soil 237:239-248. 
Tabacco, E., F. Righi, A. Quarantelli \& G. Borreani, 2010. Dry matter and nutritional losses during aerobic deterioration of corn and sorghum silages as influenced by different lactic acid bacteria inocula. J. Dairy Sci. 94 :1409-1419.

Theuretzbacher F., P. Kravanja, M. Becker, A. Bauer, B. Amon, A. Friedl, A. Potthast \& T. Amon, (2012). Utilization of sweet sorghum as a catch crop for providing raw materials for the production of bioethanol and biogas, Chemical Engineering Transactions, 29, 1135-1140.

Van de Goor, S., N. van Eekeren, A. de Vliegher, J. Pannecoucque, B. Vandecasteele \& J. van Waes, 2017. Sorghum als derde gewas in de melkveehouderij. Perspectieven van rassen en gewasrotatie in beeld. Louis Bolk Instituut i.s.m. ILVO (Instituut voor Landbouw- en Visserijonderzoek), Driebergen, $23 \mathrm{pp}$.

Van den Pol-van Dasselaar, A. \& A.C.M.M. Boomaerts, 2000. Vergelijking van teelt van Gehele Plant Silage en teelt van snijmaïs in Limburg. PR-rapport 190, PR Lelystad, 30 pp.

Van Eekeren, N. \&J. Deru. 2014. Sorghum droogtetolerant alternatief voor snijmais. V-focus, februari 2014: 16-17.

Van der Fels-Klerx, C. Liu \& P. Battilani, 2016. Modelling climate change impacts on mycotoxin contamination. World Mycotoxin Journal, 2016; 9 (5): 717-726.

Van Schooten, H.A., 2017. Handboek snijmaïs. Wageningen Livestock Research, Wageningen, 203 pp.

Vogel, E., D. Deumlich, M. Kaupenjohann, 2016. Bioenergy maize and soil erosion - Risk assessment and erosion control concepts. Geoderma 261 (2016) 80-92.

Wagenaar, J.-P. \& J. de Wit, 2003. Gehele Plant Silage (GPS): ervaringen uit de praktijk. Publicatienummer LV51, Louis Bolk Instituut, Driebergen, $40 \mathrm{pp}$.

Williams, R.J., R.A. Frederiksen \& L.K. Mughogho. Ed. G.D. Bengston, 1980. Sorghum diseases: a second world review. International Crops Research Institute for the Semi Arid Tropics, $469 \mathrm{pp}$.

Windpassinger, S.M., 2016. Breeding strategies for the adaptation of sorghum (Sorghum bicolor L. Moench) as a novel crop for temperate Europe. Dissertation, Justus-Liebig-University Giessen, Institute of Plant Breeding and Agronomy I, Department of Plant Breeding, $92 \mathrm{p}$.

Young, K.J . \& S.P. Long, 2000. Crop ecosystem responses to climatic change: Maize and Sorghum. In: Reddy, R.R., and H.F. Hodges (eds.) Climate change and global crop productivity. Mississipi State University, United States.

Zeise, K. \& M. Fritz, 2014. Sorghum für die Verwendung in Biogasanlag. Biogas Forum Bayern, 10 pp. 


\section{Bijlage 1 Drogestofpercentages sorghum}

Drogestofpercentages van 22 lijnen sorghum bij 4 zaaidata (in procenten)

\begin{tabular}{|c|c|c|c|c|c|c|}
\hline \multirow[t]{2}{*}{ Lijn/ ras } & \multirow[t]{2}{*}{ Naam ras } & \multirow[t]{2}{*}{ No Zaad, g } & \multicolumn{4}{|c|}{ Zaaidatum } \\
\hline & & & $7-5-2016$ & $14-5-2016$ & $30-5-2016$ & $14-6-2016$ \\
\hline & & & $171 \mathrm{dnz} *$ & $164 \mathrm{dnz}$ & $151 \mathrm{dnz}$ & $136 \mathrm{dnz}$ \\
\hline 1 & Sorghum nigricans & 2.5 & 42.4 & 41.5 & 42.9 & 33.2 \\
\hline 2 & Sorghum nigricans & 5 & 40.3 & 41.3 & 42.7 & 37.1 \\
\hline 3 & Sorghum nigricans & 7.5 & 38.1 & 45.1 & 41.6 & 35.8 \\
\hline 4 & Sorghum nigricans & 10 & 35.4 & 43.5 & 42.7 & 34.7 \\
\hline \multirow[t]{3}{*}{5} & Sorghum nigricans & 5 & 42.9 & 42.3 & 43.5 & 40.1 \\
\hline & S. nigricans, Gemidd. & & 39.8 & 42.7 & 42.7 & 36.2 \\
\hline & $\mathbf{C V} * *$ & & 0.08 & 0.04 & 0.02 & 0.07 \\
\hline 6 & Sorghum bicolor & 5 & 29.2 & 28.1 & 29.0 & 29.9 \\
\hline 7 & Sorghum bicolor & 2.5 & 33.8 & 30.2 & 26.8 & 27.0 \\
\hline 8 & Sorghum bicolor & 5 & 35.1 & 30.9 & 33.1 & 28.0 \\
\hline 9 & Sorghum bicolor & 7.5 & 31.3 & 32.4 & 27.2 & 26.4 \\
\hline 10 & Sorghum bicolor & 10 & 31.1 & 30.0 & 29.6 & 27.7 \\
\hline 11 & Sorghum bicolor & 5 & 32.2 & 30.9 & 35.3 & 28.7 \\
\hline 12 & Sorghum bicolor & 5 & 28.3 & 29.7 & 30.9 & 28.9 \\
\hline 13 & Sorghum bicolor & 5 & 30.5 & 33.7 & 33.5 & 30.3 \\
\hline 14 & Sorghum bicolor & 5 & 39.0 & 36.8 & 32.9 & 31.9 \\
\hline 15 & Sorghum bicolor & 5 & 31.3 & 36.0 & 30.7 & 31.3 \\
\hline \multirow[t]{3}{*}{16} & Sorghum bicolor & 5 & 28.9 & 29.7 & 30.6 & 27.2 \\
\hline & S. bicolor, Gemidd. & & 31.9 & 31.7 & 30.9 & 28.8 \\
\hline & CV & & 0.10 & 0.09 & 0.09 & 0.06 \\
\hline 17 & Sorghum soedangras & 5 & 33.6 & 37.1 & 39.0 & 33.5 \\
\hline \multirow[t]{3}{*}{18} & Sorghum soedangras & 5 & 41.3 & 33.9 & 35.8 & 30.5 \\
\hline & S. soedangras, Gem. & & 37.4 & 35.5 & 37.4 & 32.0 \\
\hline & CV & & 0.15 & 0.06 & 0.06 & 0.07 \\
\hline 19 & S. bicolor $\times$ S. bicolor & 2.5 & 32.9 & 28.9 & 26.4 & 25.2 \\
\hline \multirow[t]{3}{*}{20} & S. bicolor $\times$ S. nigric. & 2.5 & 39.7 & 37.5 & 35.7 & 29.8 \\
\hline & S. bic x S., Gemidd. & & 36.3 & 33.2 & 31.0 & 27.5 \\
\hline & cV & & 0.13 & 0.18 & 0.21 & 0.12 \\
\hline 21 & Pennisetum glaucum & 5 & 26.3 & 22.1 & 23.4 & 19.1 \\
\hline \multirow[t]{3}{*}{22} & Pennisetum glaucum & 5 & 26.8 & 28.2 & 28.1 & - \\
\hline & P. glaucum, Gemidd. & & 26.6 & 25.1 & 25.8 & - \\
\hline & CV & & 0.01 & 0.17 & 0.13 & - \\
\hline
\end{tabular}

$* d n z=\ldots$ dagen na zaaien geoogst

** $\quad \mathrm{CV}=$ variatiecoëfficiënt 

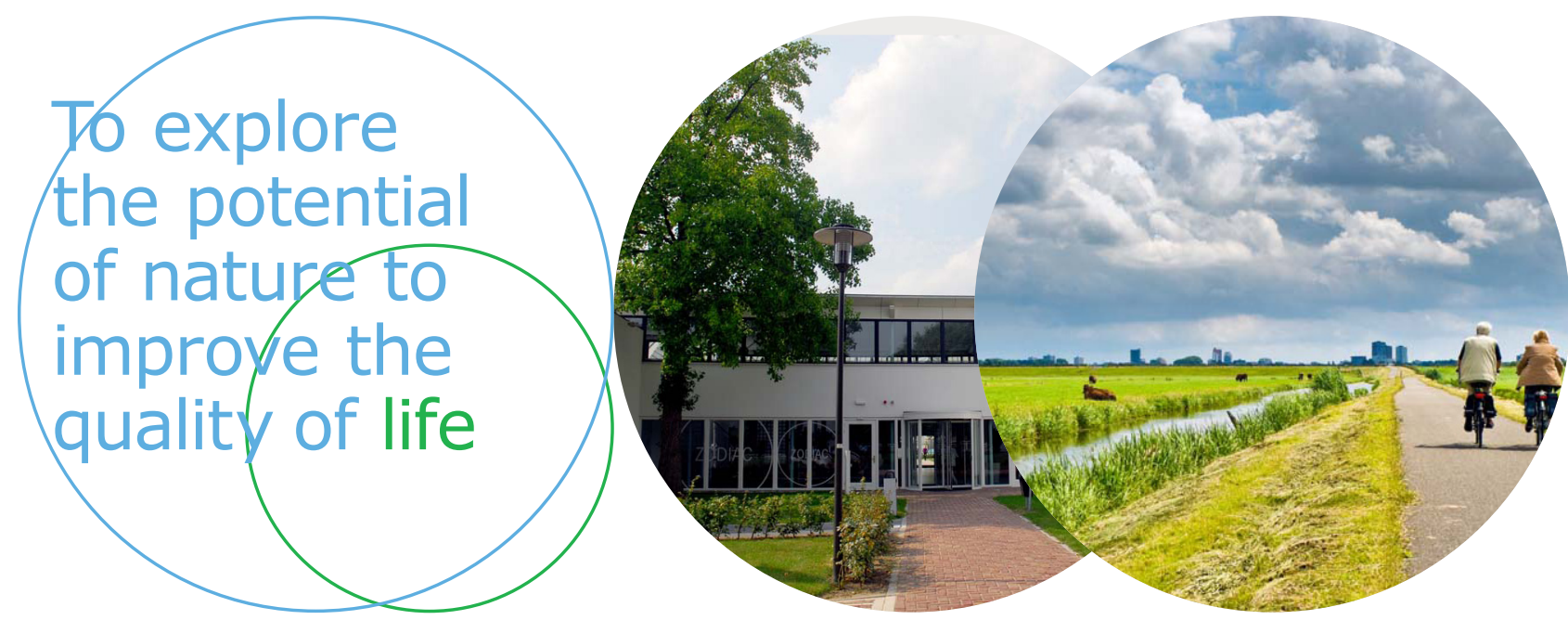

Wageningen Livestock Research Postbus 338

Wageningen Livestock Research ontwikkelt kennis voor een zorgvuldige en $6700 \mathrm{AH}$ Wageningen

T 0317483953

renderende veehouderij, vertaalt deze naar praktijkgerichte oplossingen en innovaties, en zorgt voor doorstroming van deze kennis. Onze wetenschappelijke

E info.livestockresearch@wur.nl www.wur.nl/ livestock-research kennis op het gebied van veehouderijsystemen en van voeding, genetica, welzijn en milieu-impact van landbouwhuisdieren integreren we, samen met onze klanten, tot veehouderijconcepten voor de $21 \mathrm{e}$ eeuw.

De missie van Wageningen University \& Research is 'To explore the potential of nature to improve the quality of life'. Binnen Wageningen University \& Research bundelen 9 gespecialiseerde onderzoeksinstituten van Stichting Wageningen Research en Wageningen University hun krachten om bij te dragen aan de oplossing van belangrijke vragen in het domein van gezonde voeding en leefomgeving. Met ongeveer 30 vestigingen, 6.500 medewerkers en 10.000 studenten behoort Wageningen University \& Research wereldwijd tot de aansprekende kennisinstellingen binnen haar domein. De integrale benadering van de vraagstukken en de samenwerking tussen verschillende disciplines vormen het hart van de unieke Wageningen aanpak. 